Review

\title{
Geopolymers as Alternative Sustainable Binders for Stabilisation of Clays-A Review
}

\author{
Jeremiah J. Jeremiah *(D), Samuel J. Abbey (D, Colin A. Booth (D) and Anil Kashyap \\ Faculty of Environment and Technology, University of the West of England, Bristol BS16 1QY, UK; \\ samuel.abbey@uwe.ac.uk (S.J.A.); colin.booth@uwe.ac.uk (C.A.B.); anil.kashyap@uwe.ac.uk (A.K.) \\ * Correspondence: jeremiah.jeremiah@uwe.ac.uk
}

Citation: Jeremiah, J.J.; Abbey, S.J.;

Booth, C.A.; Kashyap, A.

Geopolymers as Alternative

Sustainable Binders for Stabilisation of Clays-A Review. Geotechnics 2021, 1, 439-459. https://doi.org/10.3390/ geotechnics1020021

Academic Editors: Brendan C. O'Kelly and George Mylonakis

Received: 20 September 2021 Accepted: 24 November 2021 Published: 29 November 2021

Publisher's Note: MDPI stays neutral with regard to jurisdictional claims in published maps and institutional affiliations.

Copyright: (c) 2021 by the authors. Licensee MDPI, Basel, Switzerland. This article is an open access article distributed under the terms and conditions of the Creative Commons Attribution (CC BY) license (https:/ / creativecommons.org/licenses/by/ $4.0 /)$.

\begin{abstract}
The need to transit to greener options in soil stabilisation has revamped research on the use of industrial and agricultural by-products in order to cut down on the current carbon footprint from the use of ordinary Portland cement (OPC) and lime related binders for the treatment of problematic soils. This study is a review on the use of geopolymers constituted by alkali activation of several industrial wastes such as pulverised fuel ash (PFA), ground granulated blast furnace slag (GGBS), metakaolin (MK), glass powder (GP), palm oil fuel ash (POFA), silica fume (SF), rice husk ash (RHA), volcanic ash (VA), and marble powder (MP) for the stabilisation of weak clays. The performance of stabilised clays as subgrade and subbase materials for road pavement construction was evaluated by comparing the 7 day UCS of the treated clays with the strength requirement for stabilised materials as outlined in BS EN 16907-4. The result of the study shows that geopolymers can be employed in improving the engineering properties of problematic clays to meet practical applications. Strength improvement was observed in the stabilised clays with increased precursor content, molarity of alkaline activator, and curing period.
\end{abstract}

Keywords: geopolymers; alkaline activator; industrial by-products; stabilisation; subgrade materials; subbase materials; unconfined compressive strength; carbon footprint

\section{Introduction}

Engineering facilities such as road pavements, buildings, bridges, tunnels etc., will oftentimes be sited on geographical locations characterised by poor ground conditions. These weak soil behaviours lead to large volume instability when loaded. Under such circumstances, it becomes imperative to engineer the ground to meet design strength specifications. These procedures are generally referred to as ground improvement or soil stabilisation and maybe mechanical or chemical in methodology. Commonly encountered problems such as collapsible soils and expansive clays will often demand a chemical treatment method for which cement and lime have been successfully utilised with well documented results in various engineering applications [1]. Widely referenced engineering properties desirable in practice have been obtained using Ordinary Portland Cement (OPC) and various types of limes for hydration reaction and final precipitation of cementitious compounds such as calcium silicates hydrates (CSH) and calcium aluminate hydrates $(\mathrm{CAH})$ [2-14]. However, despite the advantages and multifaceted utilisation of cement and lime, the recent quest for a reduction in the alarming rate of environmental pollution via continuous emission of $\mathrm{CO}_{2}$ has revamped the search for new sustainable cementitious additives [15] to lower the already heightened $8 \%$ contribution from cement and lime related binders [16,17]. Figure 1 shows significant increase in $\mathrm{CO}_{2}$ over the last 100 years from cement production. 


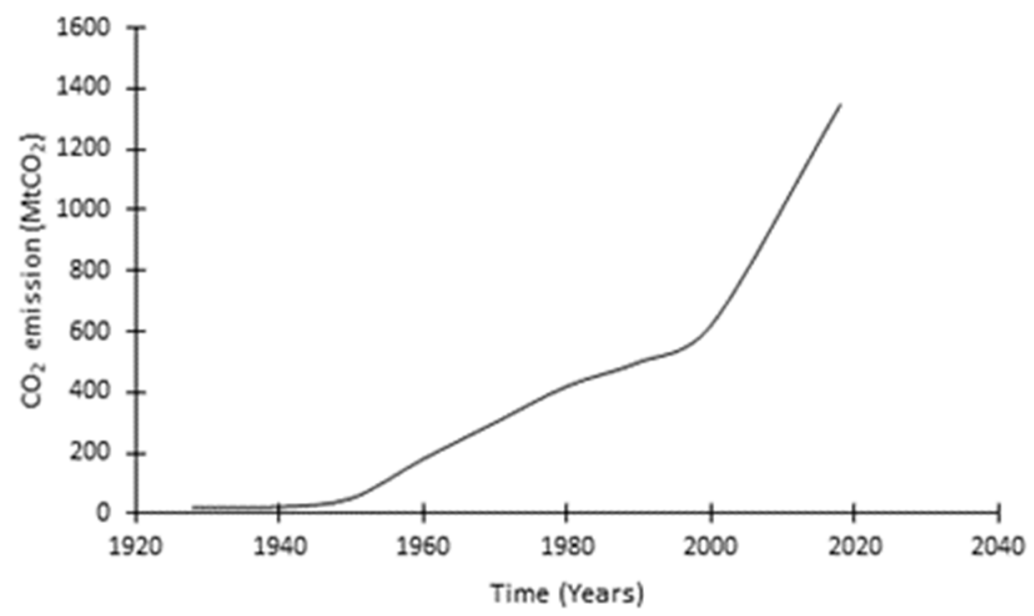

Figure 1. Global carbon emission from cement production from 1928-2018 [18].

Sequel to the foregoing, the use of by-product materials from agricultural and industrial processes have received increased attention in recent years, due to their combined low carbon footprint and alternative waste disposal advantage. Materials such as GGBS, PFA, MS, PSA, POFA, RHA, RGP etc., with rich aluminate-silicate content have generally been seen as partial replacement for Ordinary Portland Cement (OPC) for pozzolanic reaction. The continuous generation of these industrial and agricultural wastes still far exceed available options of recycling for useful purposes. However, with alkali activation, the possibility of $100 \%$ utilisation of these by-products as geopolymers have become a major research focus. Geopolymers are basically inorganic 3-dimensional long-chain minerals formed from substances rich in alumina $\left(\mathrm{Al}_{2} \mathrm{O}_{3}\right)$ and silica $\left(\mathrm{SiO}_{2}\right)$ by the dissociation of $\mathrm{Al}$ and $\mathrm{Si}$ in an aqueous solution commonly of sodium or potassium $(\mathrm{NaOH}$ or $\mathrm{KOH})$. The dissociated $\mathrm{Al}$ and $\mathrm{Si}$ realign in a fast chemical reaction to form long-chain tetrahedrons of $\mathrm{AlO}_{4}$ and $\mathrm{SiO}_{4}$ such as polysialate (Si-O-Al-O-), polysialate-siloxo (Si-O-Al-O-Si-), polysialate-disiloxo (Si-O-Al-O-Si-O-) with crosslinks creating an array of rings of amorphous or semi-crystalline matrix held by strong ionic bonds as shown in Figure 2. The charge balance in the chemical structure is maintained by the presence of the alkali metals $\left(\mathrm{Na}^{+}, \mathrm{K}^{+}\right.$or $\left.\mathrm{Li}^{+}\right)$, usually common in the activator solution, creating a creating a stable 3-dimensional structure resembling that of zeolite, capable of increasing the strength of weak soils without the need for calcium [19].

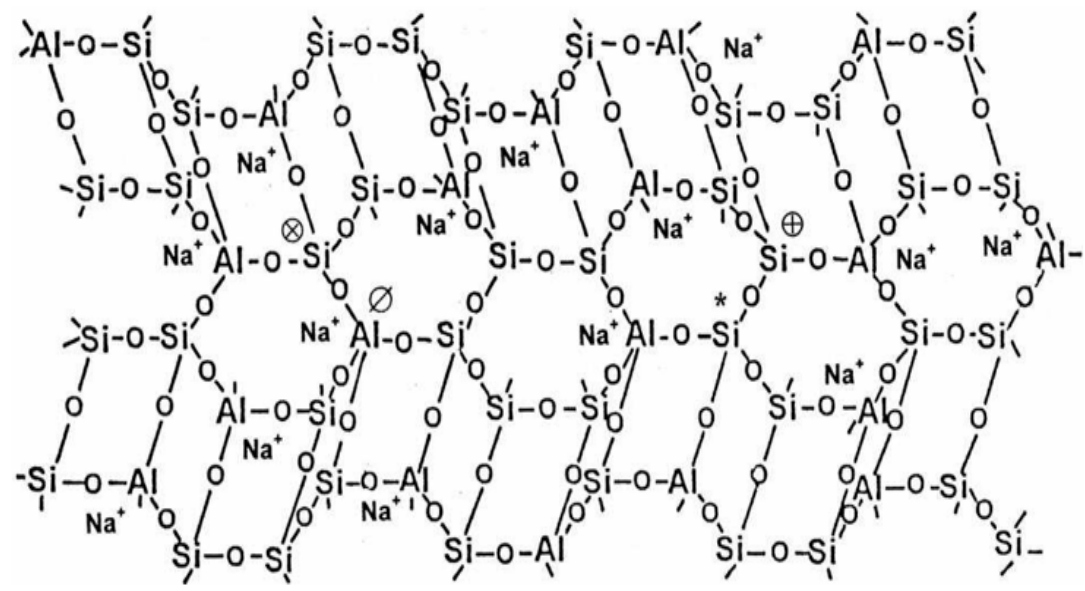

Figure 2. Chemical structure of a geopolymer [20].

One major advantage of geopolymers is that strengthening is achieved at room temperatures which makes it a practical method. An additional advantage is the ability to cement soils without necessarily requiring calcium, leading to a cut-down in $\mathrm{CO}_{2}$ emission. 
Geopolymers have been found suitable for several applications including thermal resistant coatings, ceramics manufacturing, storage and treatment containments of hazardous substances and highly reactive chemicals. Furthermore, the continuous generation of industrial by-products or waste materials rich in $\mathrm{Al}_{2} \mathrm{O}_{3}$ and $\mathrm{SiO}_{2}$ encourages the use of these materials as sources of alumina and silica for geopolymerisation and soil stabilisation. Table 1 highlights some major differences in the use of geopolymers and OPC.

Table 1. Comparison of a Typical Geopolymer and OPC.

\begin{tabular}{|c|c|c|}
\hline Parameter & Geopolymer & OPC \\
\hline $\begin{array}{c}\text { Energy consumption (calcination and } \\
\text { crushing) }\end{array}$ & $990 \times 106 \mathrm{~J} /$ ton * & $3430 \times 106 \mathrm{~J} /$ ton $^{* *}$ \\
\hline Carbon emission & Low $(169 \mathrm{~kg} \mathrm{CO} 2 / \mathrm{m} 3) * *$ & High $(306 \mathrm{~kg} \mathrm{CO} 2 / \mathrm{m} 3) *$ \\
\hline Environmental impact & Alternative waste management solution & Release of cement kiln dust (CKD) \\
\hline Major raw material & Industrial and agricultural wastes. & Limestone, shale, rocks etc. \\
\hline Thermal characteristics & Higher resistance to high temperatures & Lower resistance to high temperatures \\
\hline Chemical process & Geopolymerisation & Hydration \\
\hline Calcium requirement & Not necessarily & Required \\
\hline Resultant cementing compound & $\begin{array}{l}\text { Sodium or potassium aluminate-silicate } \\
\text { hydrates }(\mathrm{Na}, \mathrm{K}, \mathrm{Li}, \mathrm{Ca}-\mathrm{A}-\mathrm{S}-\mathrm{H})\end{array}$ & $\begin{array}{l}\text { Calcium silicate hydrate }(\mathrm{C}-\mathrm{S}-\mathrm{H}) \text { and } \\
\text { calcium aluminate hydrate }(\mathrm{C}-\mathrm{A}-\mathrm{H})\end{array}$ \\
\hline Carbonation effects & $\begin{array}{c}\text { Results in lowered } \mathrm{pH}(10-10.5) \text { which } \\
\text { still resists corrosion of steel } \\
\text { reinforcement }\end{array}$ & $\begin{array}{l}\text { Results in lower } \mathrm{Ph}(7-8) \text { leading to } \\
\text { increased rate of corrosion of steel } \\
\text { reinforcement }\end{array}$ \\
\hline Alkali-aggregate reaction (AAR) & $\mathrm{No}^{* *}$ & Yes ** \\
\hline
\end{tabular}

\section{Geopolymerisation}

The synthesis of Si-O-Al-O monomers through geopolymerisation results in the formation of inorganic polymers with strong ionic bonds which can be generically represented as stated below.

$$
\mathrm{M}_{\mathrm{X}}\left[-\left(\mathrm{Si}-\mathrm{O}_{2}\right)_{\mathrm{Y}}-\mathrm{Al}-\mathrm{O}\right] \times \cdot \mathrm{zH}_{2} \mathrm{O}
$$

where $\mathrm{M}$ is the alkali, $\mathrm{x}$ is the degree of polymerisation, $\mathrm{y}$ is an integer defined as 1, 2, 3 and so on. Three basic components are required for geopolymerisation as shown in Figure 3. Depending on the temperatures at which the reaction occurs, the structure of geopolymers could be amorphous or semi-crystalline.

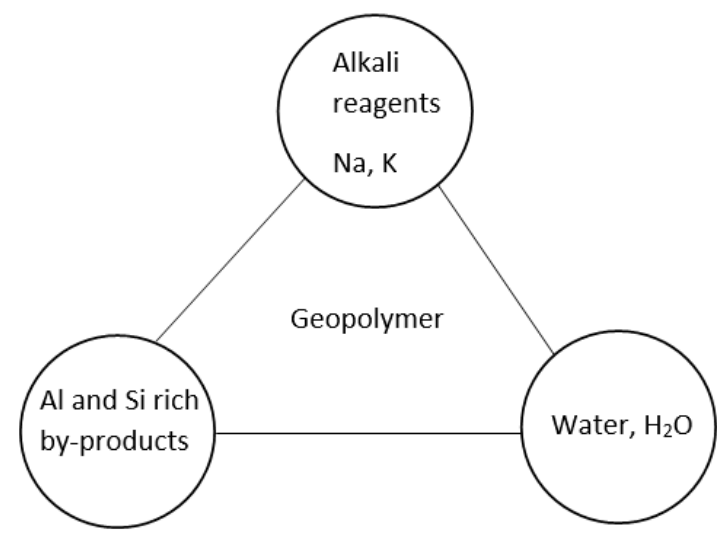

Figure 3. Constituent Materials for Geopolymer Production.

Geopolymerisation is a "green route" in production of resins, binders, and cements [22]. The synthesis of geopolymer involves a multi-step procedure which can be simplified into 
the dissociation of aluminium and silicon in an alkaline solution, followed by the realignment of free aluminium and silicon tetrahedra, before condensation, polymerisation, and hardening. The entire process may be considered as either dry or wet synthesis [23]. The authors have found the wet type of synthesis to be more commonly employed and involves the use of an alkali solution or combination of alkaline liquids which is then utilised in dissociating $\mathrm{Al}$ and $\mathrm{Si}$ in the precursor to form the fresh geopolymer paste. On the other hand, in the dry process, dry samples of the precursor and alkali activators are mixed thoroughly, and water is then added based on a predefined water-binder ratio to achieve target molarity. Figure 4 gives a breakdown of the synthesis of geopolymer.

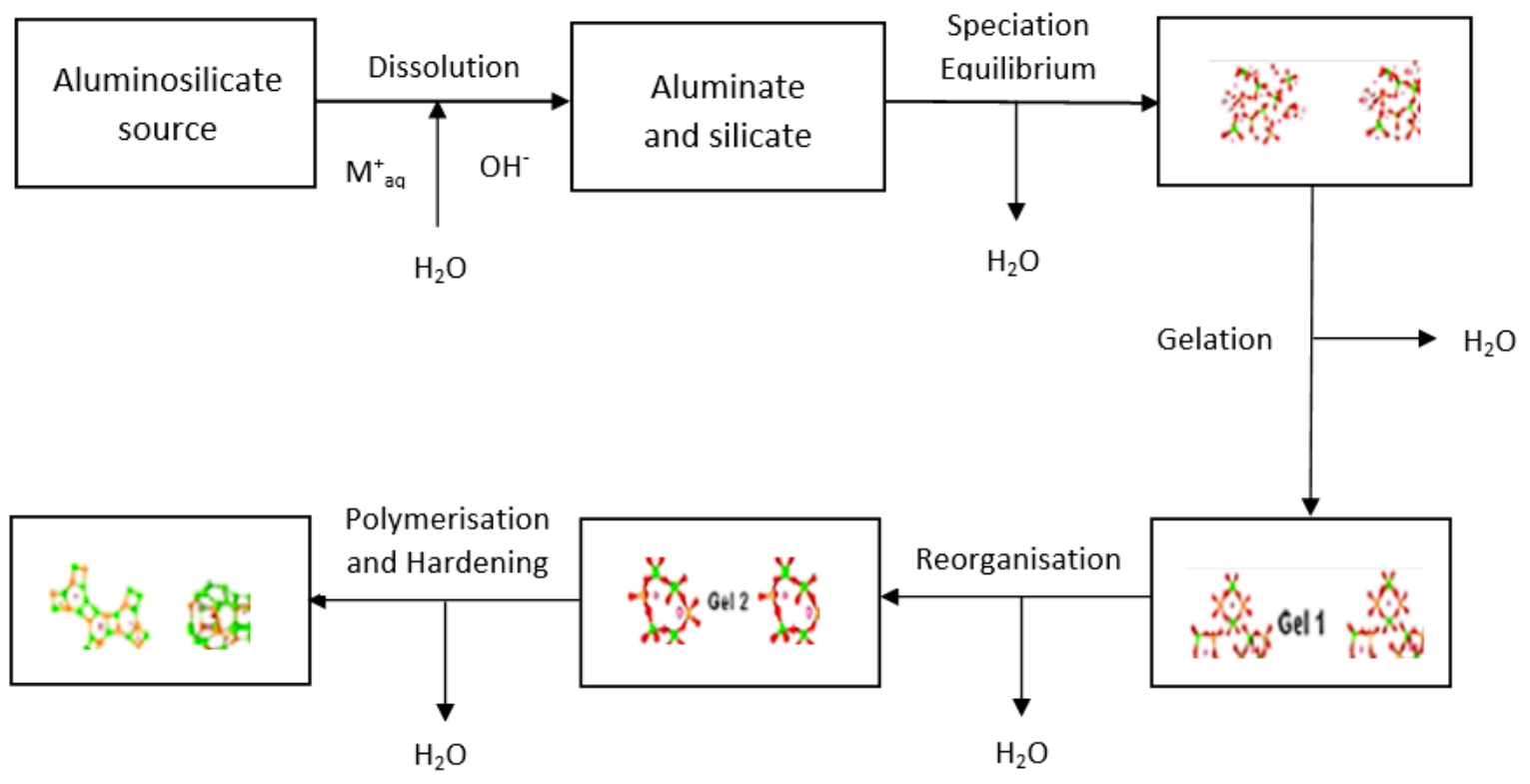

Figure 4. Steps in Geopolymer Synthesis [21].

\subsection{Activator Liquid}

Activator liquid are aqueous solutions utilised in dissociation or release of $\mathrm{Al}$ and $\mathrm{Si}$ from the original precursors for geopolymerisation. Common activators solution may be alkaline, or acid salt solutions as reported by [24]. However, the alkaline solutions are the most common activators used in research. For example, sodium hydroxide $(\mathrm{NaOH})$ or potassium hydroxide $(\mathrm{KOH})$ as single activators [25] or in combination with sodium silicate $\left(\mathrm{Na}_{2} \mathrm{SiO}_{3}\right)$ or potassium silicate $\left(\mathrm{K}_{2} \mathrm{SiO}_{3}\right)$ to expedite the reaction rate [26,27] for the formation of strength-giving compounds such as sodium-aluminosilicate hydrate (N-A-S-H). The type and amount of activator or mixture of activators utilised for geopolymerisation with Al-Si resource influences the porosity and bond strength of the resulting geopolymer $[28,29]$. A low workability has been reported when $\mathrm{NaOH}$ was used as a single activator due to high plasticity of the resulting geopolymer. Whereas an improved workability was seen upon addition of $\mathrm{Na}_{2} \mathrm{SiO}_{3}$. Some studies $[30,31]$ showed that increasing $\mathrm{Na}_{2} \mathrm{SiO}_{3}$ in the presence of $\mathrm{NaOH}$ increased the compressive strength of the geopolymers while the absence of $\mathrm{NaOH}$ resulted in a reduction in the strength. However, this depends on the temperature as $\mathrm{NaOH}$ primarily aids the dissociation of the geopolymer precursor (Al-Si units) at lower temperatures. Upon increased temperatures say $80^{\circ} \mathrm{C}, \mathrm{Na}_{2} \mathrm{SiO}_{3}$ may be utilised as a single activator without reduction in strength as the increased temperature aids the breakdown of the existing bonds within the starting material for the dissociation of Al-Si units [32]. Since the hydroxide and silicate combination of the activator both contribute to the quality of the resulting geopolymer, it is logical to conclude that there is an optimum ratio of $\mathrm{NaOH}$ to $\mathrm{Na}_{2} \mathrm{SiO}_{3}$ for best performance [25]. $\mathrm{Na}_{2} \mathrm{SiO}_{3}$ has the added advantage of compensating for shortage in silicon in the precursor leading to increase in bond strength with a reduction in porosity. In terms of molarity of $\mathrm{NaOH}$ solution for geopolymerisation, reference [33] 
has reported a lower limit of 12 for adequate synthesis of geopolymers. Whereas [34] has reported a molarity of 20 as an upper limit for the activator. Furthermore, the cost effectiveness of alkali activator ingredients in terms of energy consumption has also been raised [35-38]. For example, it is reported that 39\% and 49\% energy consumption is associated with the production of $\mathrm{NaOH}$ and $\mathrm{Na}_{2} \mathrm{SiO}_{3}$ respectively, and also contributes to the overall cost of the geopolymer. To maintain low-cost energy requirements for these activators, an alternative waste solution that is rich in aluminosilicates can be sourced. One option is the Bayer's solution as suggested in [38].

\subsection{Geopolymer Precursors}

Soil strength is a direct result of the bonds and interparticle connections-improving this bond is the major focus of any chemical method of ground improvement. Geopolymers are receiving more attention in stabilisation of clays due to their environmentally friendly nature. Several studies have explored different types of materials such as PKA, GGBS, RHA, PSA, PFA, etc., in obtaining the needed aluminosilicates for geopolymerisation and have proven geopolymers to be highly effective in improving the strength of various soils. However, according to $[1,17,27,39]$, there still exists a huge lump-sidedness between theory and practical engineering applications. The authors believe this gap is largely from cost implications from large scale procurement of alkaline activator compounds, but also from an insufficient database upon which useful post-stabilisation behaviour could at least be inferred under practical conditions. For this reason, in this section, several studies are discussed, and major findings are presented. The major requirement of a geopolymer precursor is a sufficient amount of aluminium and silicon oxide. This requirement as already well-known, has been satisfied by many natural sources and waste materials or by-products from several industrial processes and agricultural activities including PFA, GGBS, PSA, RHA, POFA, MK, and VA to mention a few as shown in Table 2. Hence, the chemical and physical properties of the source material is a key influence on the mechanical properties of the final product after geopolymerisation.

Table 2. Percentage Chemical Composition of Common By-product Materials for Geopolymerisation [40,41].

\begin{tabular}{cccccccccccc}
\hline Chemical Compound & OPC & FA-F & FA-C & GGBS & BA & RHA & GP & SF & MP & VA \\
\hline $\mathbf{C a O}$ & 62.58 & 4.24 & 23.9 & 36.42 & 6.13 & 1.14 & 8.21 & 1.35 & 52.45 & 19.1 \\
\hline $\mathbf{A l}_{\mathbf{2}} \mathbf{O}_{3}$ & 5.31 & 24.4 & 7.97 & 10.6 & 34.3 & 0.54 & 1.00 & 0.39 & 0.39 & 13.5 \\
\hline $\mathrm{Fe}_{\mathbf{2}} \mathbf{O}_{\mathbf{3}}$ & 4.04 & 7.1 & 5.34 & 1.28 & 15 & 0.16 & 0.52 & 1.21 & 0.78 & 8.5 \\
\hline $\mathrm{SO}_{3}$ & 2.73 & 0.29 & 3.03 & 0.68 & 0.9 & 0.25 & 0.06 & 1.00 & 0.076 & 0.3 \\
\hline $\mathbf{M g O}$ & 2.82 & 2.4 & 0.53 & 7.63 & 1.57 & 0.5 & 0.14 & 2.23 & 0.54 & 1.7 \\
\hline $\mathrm{SiO}_{\mathbf{2}}$ & 20.25 & 57.2 & 18.27 & 40.4 & 39.4 & 87.2 & 78 & 92.5 & 1.29 & 46.8 \\
\hline $\mathbf{K}_{\mathbf{2}} \mathbf{O}$ & 0.92 & 3.37 & 1.39 & $\mathrm{NR}$ & 1.19 & 1.94 & 0.09 & 0.08 & 0.11 & 4.3 \\
\hline
\end{tabular}

NR-Not reported, OPC—ordinary Portland cement, FA-F—class F pulverised fuel ash, FA-C—class C pulverised fuel ash, RHA-rice husk ash, GGBS—ground granulated blast furnace slag, BA—bottom ash, GP—glass powder, SF—silica fume, MP—marble powder, VA-volcanic ash.

\subsubsection{Pulverised Fuel Ash-Based Geopolymers}

PFA is perhaps the most used material for geopolymerisation. However, PFA is still underutilised as a geopolymer resource in terms of soil stabilisation [42]. The strength of geopolymer stabilised soils is influenced by several factors including the amount and type of the alkaline liquid and its molarity, the amount and type of the precursor used, the curing temperature, etc. In addition, the performance of PFA geopolymer treated clays will depend on important properties of the clay such as plasticity and cation exchange capacity. Moreover, for class C PFA geopolymers, high calcium content has been reported to influence the long-term strength of the stabilised soils by interfering with aluminasilicate chains during polymerisation. However, an advantage of high calcium PFA is a 
possibility of combined geopolymeric and pozzolanic products. In the study by [27], the performance of PFA in combination with calcium carbide residue in the treatment of a soft marine clay was evaluated. An important highlight of the study was the strength improvement in the stabilised soil by additional strength yielding compounds (CSH and $\mathrm{CAH}$ ) from pozzolanic reactions. The UCS of the samples showed that the strength of the stabilised soils increased due to the presence of CSH and CAH in combination with N-A-S$\mathrm{H}$ compounds which enhanced early development of bond strength of the treated soils. Furthermore, an optimum sodium silicate-sodium hydroxide ratio of $70 \% \mathrm{Na}_{2} \mathrm{SiO}_{3}$ and $30 \% \mathrm{NaOH}$ was reported. An appropriate $\mathrm{Na}_{2} \mathrm{SiO}_{3}$ and $\mathrm{NaOH}$ ratio would usually result in sufficient dissociation of $\mathrm{Al}-\mathrm{O}$ and $\mathrm{Si}-\mathrm{O}$ for synthesis and polycondensation. However, this would obviously lead to a much slower strength development due to the slow rate of geopolymerisation at room temperature.

In a separate study, reference [43] evaluated the effectiveness of high calcium PFA in improving the properties of marginal lateritic soils. A comparison of 7-day UCS of samples cured at room temperature for various ratios of $\mathrm{Na}_{2} \mathrm{SiO}_{3}$ and $\mathrm{NaOH}$ showed that samples treated with $90 \% \mathrm{Na}_{2} \mathrm{SiO}_{3}$ and $10 \% \mathrm{NaOH}$ had higher strength $(7100 \mathrm{kPa})$. However, at 90 days curing, the strength of samples treated with $\mathrm{Na}_{2} \mathrm{SiO}_{3}-\mathrm{NaOH}$ ratio of 0.5 performed better with UCS exceeding $\mathrm{kPa}$ as expected. Furthermore, reference [44] studied the effects of PFA geopolymer on a soft clay using $\mathrm{NaOH}$ and $\mathrm{Na}_{2} \mathrm{SiO}_{3}$ alkaline activator. The UCS of treated samples increased up to kPa after 28 days curing. Although the rate of strength gain was slow with higher $\mathrm{NaOH}$, the long-term strength gain was eventually higher when compared with OPC treated samples. Furthermore, reference [45] utilised a PFA-based geopolymer in stabilising a soft silty clay using a mixture of $\mathrm{Na}_{2} \mathrm{SiO}_{3}$ and $\mathrm{NaOH}$ as with previous studies. As expected, the strength of the treated samples increased with increasing activator-PFA ratio up to a maximum value before reducing. The optimum $\mathrm{Na}_{2} \mathrm{SiO}_{3}-\mathrm{NaOH}$ ratio was found at 0.7 with an activator liquid to PFA ratio of 0.6 . A high plasticity clay was treated with PFA-GGBS geopolymer in the study by [46] using a combination of $\mathrm{Na}_{2} \mathrm{SiO}_{3}$ and $\mathrm{NaOH}$. Compressibility tests on treated samples showed that the strain of the samples decreased with increasing binder content which shows increased interparticle bond strength. Moreover, it was observed that the strength and permeability of the clay was lowered due to increased cementation from the geopolymer gel.

The effect of PFA geopolymer on the volume stability of treated clays was also reported by [39]. Experimental studies on the use of PFA to improve the mechanical properties of kaolin clay showed the formation of new mineralogical structures with regards to aluminosilicate chains and crosslinks. One dimensional consolidation test on the treated samples indicated lower void ratios with increasing geopolymer content. Figure 5 shows the variation of void ratios with increasing vertical stresses from oedometer test for 7 days curing periods for samples treated with both PFA geopolymer and OPC.

PFA geopolymer treatment was effective in modifying the Atterberg properties of highly plastic clays as reported by [47]. A soft clay treated with PFA activated with calcium carbide residue (CCR) and $\mathrm{Na}_{2} \mathrm{SiO}_{3}$ showed that the consistency of the treated clays improved with reduction in $\mathrm{LL}, \mathrm{PL}$, and PI with increasing $\mathrm{Na}_{2} \mathrm{SiO}_{3}$ content. The compressive strength of the clay generally increased with increase in the geopolymer content and is in alignment with other studies. Similar improvement was observed in the experimental study by [48] which utilised a high calcium PFA based geopolymer in treating a kaolin clay. However, the formation of thenardite $\left(\mathrm{Na}_{2} \mathrm{SO}_{4}\right)$ with amorphous silicate chains and intermittent calcium oxide was observed which lowered the strength development after 7 days. The large amount of calcium bearing compounds such as $\mathrm{CaSO}_{4}, \mathrm{CaCO}_{3}$, or $\mathrm{Ca}(\mathrm{OH})_{2}$, which may be in existence in an aqueous solution of a high calcium bearing precursor, were also reported to have affected the long term strength of the stabilised soil by altering the fabric of N-A-S-H binders with patches of CSH. This is one of the reasons for the more common application of Class F PFA in geopolymerisation over class $C$ type. The experimental study by [41] compared the performance of RHA, MK, PFA, GGBS, SF, MP, and BA as geopolymer for deep mixing stabilisation of clays. From 
the study, it was observed that the UCS of GGBS and GGBS-PFA blended soil mixtures were very close to OPC treated samples. The strength of the samples also increased with increasing alkali activator to binder ratios as expected due to increasing availability of alumina and silica. An optimum alkali solution to binder ratio was also observed beyond which, the UCS decreased due to excessive moisture within the voids. Figure 6 shows the variation of UCS with precursor content for $0.85,1.0$, and 1.25 alkali solution to binder ratio. These findings are obviously appreciable steps towards establishing the usefulness of these by-products other than for landfill disposals.
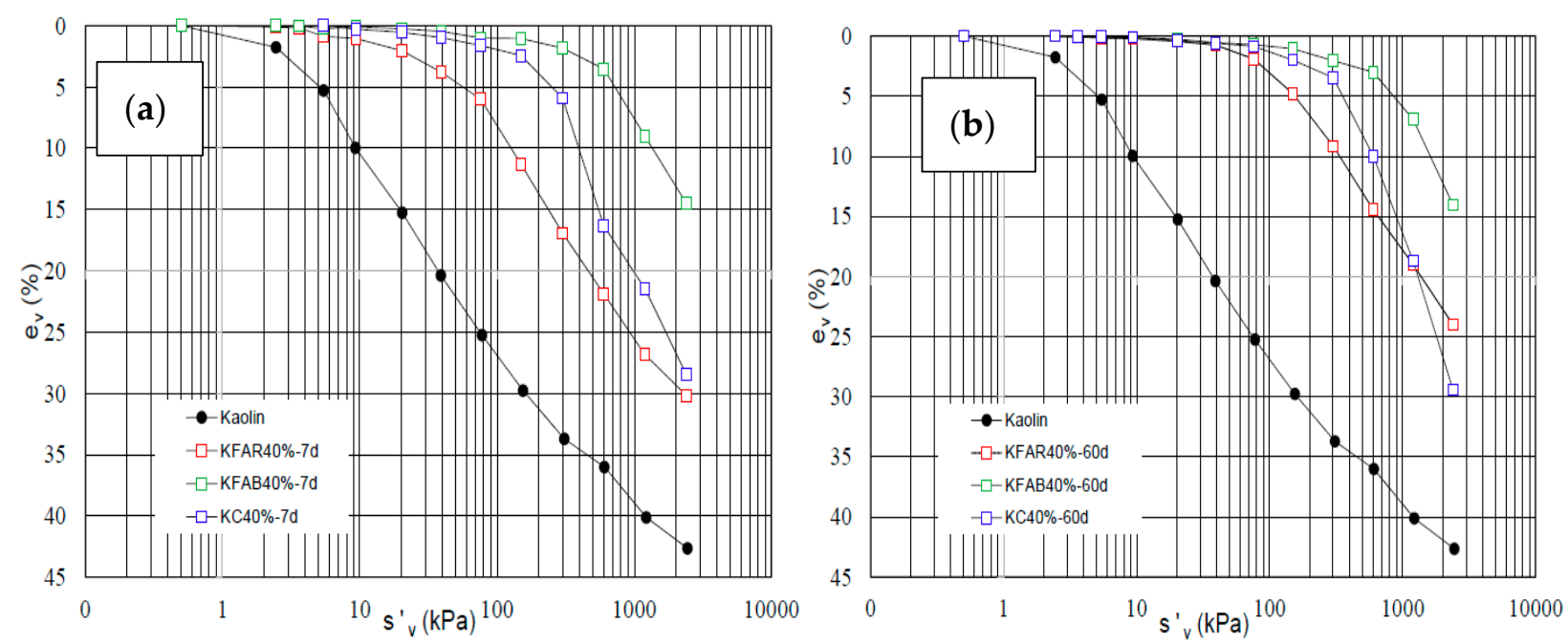

Figure 5. Consolidation Curves of Geopolymer and OPC Stabilised Clay (a) 7 days cured (b) 60 days cured [39].
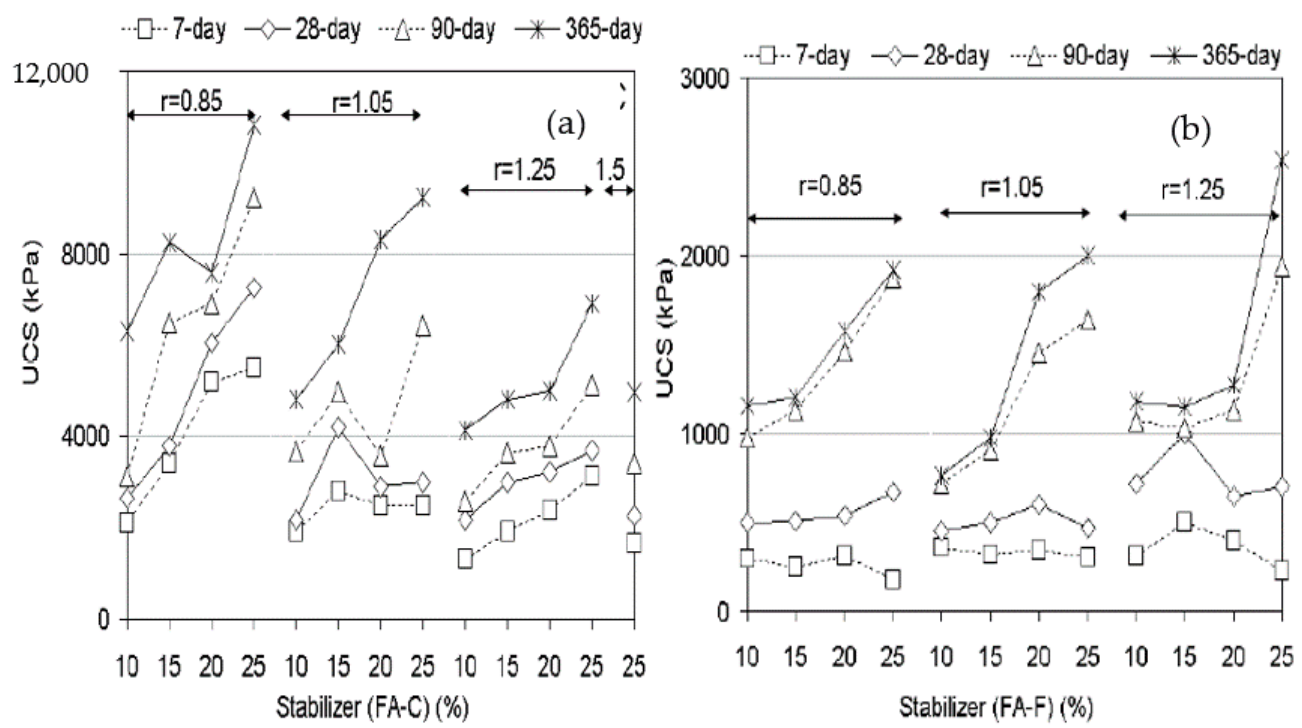

Figure 6. UCS versus binder content for PFA-based Geopolymer-stabilised Clays (a) Class C PFA (b) Class F PFA [41].

Most tests on geopolymer stabilised clays are based on static conditions of loading to evaluate effectiveness of the treatment. However, in-situ conditions of highway subgrades are typically dynamic in loading. To evaluate the performance of geopolymer stabilised soils under dynamic conditions, reference [42] conducted an experimental study on the performance of clays stabilised with PFA-GGBS geopolymers under dynamic loading. Samples were subjected to consolidated undrained cyclic triaxial test using $100 \mathrm{kPa}$ lateral cell pressure with a sinusoidal load function and predefined cyclic stress ratios (CSR) of $0.3,0.5$, and 0.7 . The result showed delayed incremental strain for stabilised sample when 
compared with untreated specimens. In addition, reference [49] in a separate study have reported increased yield stress when PFA and GGBS based geopolymers were used in treating a kaolin clay and some natural clay soils. The addition of GGBS to the geopolymer mixture expedited strength gain at ambient temperatures and improved the yield stress of the soil with increasing geopolymer binder content, causing the stabilised soil to show a more brittle stress-strain pattern beyond the yield point. In addition, the effective shear strength parameters also improved as expected. Furthermore, in the study by [50], class $\mathrm{F}$ and C PFA were utilised in stabilisation of a clay soil by activation with a sodium hydroxide and sodium silicates solution. UCS tests at 7 days curing showed that samples treated with Class C PFA geopolymer were higher than Class F. This could be due to the additional early strength gain due to pozzolanic reaction from $\mathrm{CSH}$ and $\mathrm{CAH}$ compounds. However, the long-term performance showed that soil samples cured with Class $\mathrm{F}$ attained higher strengths. Moreover, the results show that the long-term strength gain from geopolymerisation exceeded that of the samples treated with equal ratio of OPC. This suggests that long term strength from geopolymer-based binders may compete favourably with those of more traditional binders such as OPC and lime and agrees with [51]. PFA geopolymers have also been used to stabilise gypseous soils and improved sulphate resistance. Perhaps, geopolymer binders may also be beneficial in reducing ettringite-induced heave and expansion of expansive clays with high sulphate content. The study by [52] reported reduced collapse potential and permeability with increase UCS of PFA geopolymer treated gypseous soils. In addition, treated samples showed more resistance to sulphate attack when immersed in $\mathrm{MgSO}_{4}$. It is worthwhile to note that samples treated with $\mathrm{KOH}$ activated PFA geopolymers had higher strength than $\mathrm{NaOH}$ activated samples. The higher strength of $\mathrm{KOH}$ geopolymers can be related to the larger cation size of the $\mathrm{K}+$ compared to $\mathrm{Na}+$ which decreases the surface charge density and increases the rate of geopolymerisation. The study by [16] also evaluated the effect various ratios of $\mathrm{NaOH}$ and $\mathrm{Na}_{2} \mathrm{SiO}_{3}$ and activator liquid content on the performance of PFA-based geopolymer treated clays using a high plasticity clay. The UCS results on cured clay samples showed increasing strength with increasing activator liquid and PFA content up to a maximum value before reducing with further increase in activator liquid content. Overall, the effectiveness of PFA geopolymers in stabilisation of clays is determined by appropriate selection of binder content, molarity, and alkaline activator contents for optimum strength development.

\subsubsection{Metakaolin-Based Geopolymers}

MK has been utilised as a geopolymer precursor to produce concrete and mortars. MK-based geopolymers have shown to have very high strength properties when cured at higher temperatures. However, for practical soil stabilisation applications, ambient temperature curing would be required. In the study by [53], a MK-based geopolymer activated with $\mathrm{Na}_{2} \mathrm{SiO}_{3}$ and $\mathrm{NaOH}$ was used for stabilising a weak clay. As with other studies, the UCS of the weak clay increased with binder to soil ratio due to increased bonding from the effects of geopolymerisation. Even though the immediate strength gain indicated by 7 days UCS showed lower values for sample stabilised with less than $15 \%$ binder to soil ratio when compared with samples treated with OPC using $5 \%$ by weight of soil, the 28-day UCS was higher than OPC treated samples. Again, the study by [54] considered the use of alkali activated OPC blended with MK for stabilisation of a high plasticity clay using a combination of $\mathrm{NaOH}$ and $\mathrm{Na}_{2} \mathrm{SiO}_{3}$. The treatment of the clay was carried out at the natural moisture content of the clay by partial replacement of the clay by MK-OPC blend by weight of dry clay. The MK content was varied to investigate the effects of MK content on the UCS while the ratio of activator solution to MK-OPC blended mixture was fixed at 0.6. The results of microscopic analysis showed that alkali activation of OPC led to formation of combined C-S-H and N-A-S-H compounds which increased the UCS of the stabilised clays with addition of metakaolin. The pore structure of the treated clays also showed signs of reduced pore volume with increasing metakaolin content. It was also observed that the addition of an alkaline activator to MK-OPC mixture led to a reduction in 
amount of OPC required for same strength. Furthermore, in a study by [55], the use of MK for the stabilisation of a high plasticity clay was investigated. For dissociation of the Al-Si units, a mixture of $4 \%, 10 \%$, and $15 \%$ of MK by dry weight of clay activated by $\mathrm{KOH}$ and silica fume was used. The 28-day UCS results for samples treated with geopolymer mixture of $4 \%$ MK content was $100 \%$ higher in strength than untreated samples. The UCS increased with geopolymer content as expected. Furthermore, the volume-change of treated samples were compared with that of untreated samples from the swell and linear shrinkage tests. The tests showed that treated samples had lower volume change compared to the untreated samples. Moreover, reference [56] studied the performance of metakaolin activated with quicklime $(\mathrm{CaO})$ and sodium bicarbonate $\left(\mathrm{NaHCO}_{3}\right)$ as a geopolymer for stabilisation of a clay soil. The UCS results showed that the geopolymer-treated clays attained an optimum strength value before declining with further increase in activator liquid. The reduction in strength after optimum value was due to the excessive increase in pore fluid which resulted in weaker bonds and subsequent increase in shrinkage cracks with adverse effects on the long-term performance. Therefore, an optimum ratio of MK to activator liquid of 2:1 was reported, while the optimum ratio of the constituted geopolymer mixture to dry clay was found to be $12 \%$.

\subsubsection{GGBS and Glass Powder-Based Geopolymers}

The use of GGBS in geopolymerisation for soil stabilisation has attracted the attention of many researchers. The study by [57] considered the performance of GGBS with the addition of phosphogypsum which is largely composed of $\mathrm{CaO}$ and $\mathrm{SiO}_{3}$, to increase synthesis of the geopolymer. Results of triaxial tests conducted on the stabilised clay samples showed over $100 \%$ shear strength gain over untreated samples. In a separate study, reference [41] in exploring the viability of several pozzolans for geopolymerisation, evaluated the use of GGBS as a binder for deep mixing improvement. The UCS results of GGBS geopolymer treated clay was reported to have improved with increasing binder content as expected and with increasing alkali liquid to GGBS ratio. The 28-days UCS results of the treated soil improved for GGBS and GGBS-blended samples up to an optimum alkali liquid to GGBS content of 1.05. An experimental study by [24] compared the performance of geopolymer treated clays using GGBS and Class F PFA. activated by $\mathrm{NaOH}$ and $\mathrm{Na}_{2} \mathrm{SiO}_{3}$ at 4 to 14.5 molarities. Results of the experiments showed that GGBS-based geopolymers resulted in higher UCS of the stabilised soils and can be linked with higher dissociation of Al-Si tetrahedral units from GGBS compared to the PFA. Overall, the UCS of the clays increased with increasing binder content. This is expected as more precursor increased formation of more cementitious gel which filled up the void spaces and increased interparticle bonds.

In the experimental study by [58] the suitability of recycled glass powder GP for geopolymerisation and stabilisation of a clay soil was evaluated. The UCS results of $\mathrm{NaOH}$ activated GP showed that increasing $\mathrm{NaOH}$ content of the mixture increased the UCS of the stabilised soils. Relatively higher $\mathrm{NaOH}$ content were reported to lower the UCS of the treated soils due to increased viscosity and subsequently reduced polymerisation. However, the treated soils performed better than the untreated soils. Although as expected, samples cured under increased temperature showed better strength gain, the improvement of ambient temperature-cured samples also showed the effectiveness of RGP geopolymer in practice. In addition, reference [59] applied GP to improve the mechanical properties of a clay using a solution of calcium carbide residue (CCR) in activating the Al-Si units. The UCS test on 7, 28, and 91 days cured samples showed that CCR activated RGP resulted in formation of geopolymeric binders which increased the compressive strength when compared with samples treated with 5\% OPC. The effect of elevated curing temperatures was also observed with prolonged reactivity for increased cross-linking and higher strength for samples cured at $70^{\circ} \mathrm{C}$. The size of the glass particles can have significant impacts on the mechanical properties of GP-stabilised soils.

As is already well-known, smaller GP particles increase specific surface area which improves mixing and bonding. The study by [60] utilised $15.4 \mu \mathrm{m}$ sizes of GP particles 
blended with class F PFA for geopolymer treatment of road pavement base material and reported good reactivity. Experimental work on GP geopolymer mortars by [61] also investigated the effects of GP particle sizes on GP-geopolymer mortars by considering glass cullets with specific surface areas of $1000-4000 \mathrm{~cm}^{2} / \mathrm{g}$. Their results show satisfactory performance with increasing fineness especially for $4000 \mathrm{~cm}^{2} / \mathrm{g}$ as shown in Figure 7 . However, relatively higher GP contents can lead to deterioration in strength as reported by [60].

\section{Effects of Cullet Size on UCS of GP Geopolymers}

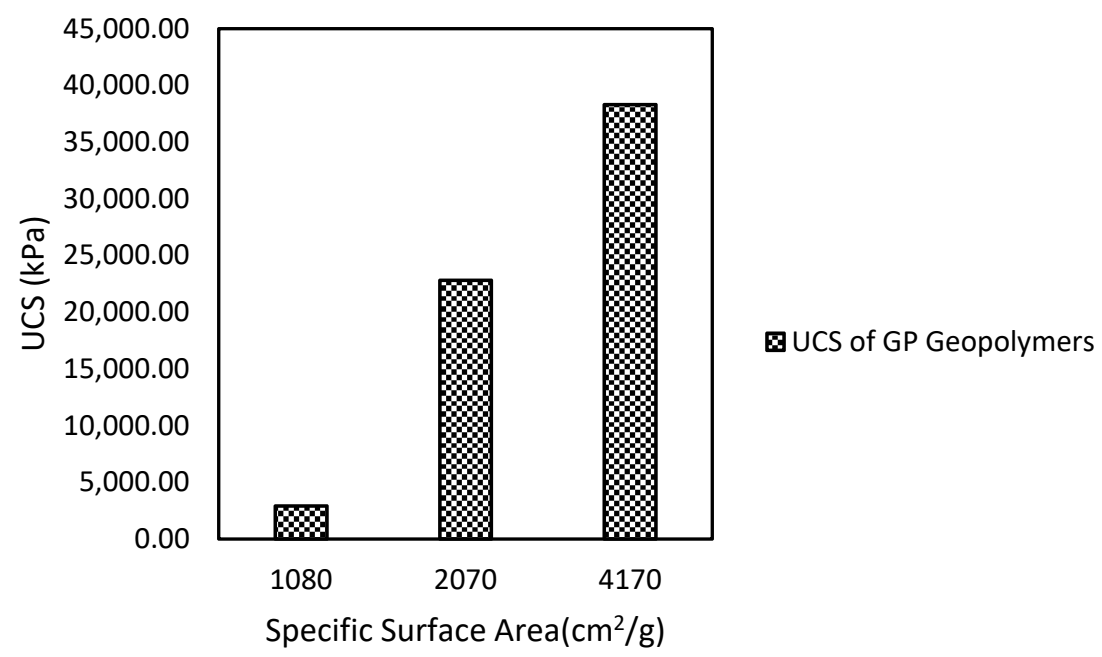

Figure 7. Effects of Cullet Sizes on UCS of GP Geopolymers [61].

\subsubsection{Palm Oil Fuel Ash and Volcanic Ash-Based Geopolymers}

Palm oil fuel ash (POFA) a by-product of palm oil production, is generated through combustion of palm kernels, palm fibres, and empty bunches of palm fruits. These raw materials for the generation of POFA are abundant in many parts of the world where palm oil is in huge production. POFA has been reported as a viable pozzolan and a good geopolymer precursor [62]. A study by [63] utilised POFA geopolymer for soil stabilisation. The POFA was activated with $\mathrm{K}_{2} \mathrm{SiO}_{3}$ and $\mathrm{KOH}$ solution which has been reported to yield faster polycondensation with stronger bonding of soil grains at room temperature. As expected, UCS of treated samples were higher with increasing binder content and curing duration when compared to untreated samples. However, more significant effect of the geopolymer was seen at elevated curing temperatures due to release of more $\mathrm{Si}-\mathrm{Al}$ units.

Volcanic ash (VA) is a naturally occurring rock mineral with rich Al-Si content from fragmented molten magmas. VA has also been explored by [40] as a soil binder through alkali activation using $\mathrm{Na}_{2} \mathrm{SiO}_{3}$ and $\mathrm{NaOH}$. The effects of key parameters such as curing duration, molarity of activator solutions, activator-binder ratio, and volcanic ash to clay ratio were evaluated based on UCS tests on treated clays and compared with cement treated samples. From the results of UCS tests, on the treated soil samples, it was observed that the volcanic ash-based geopolymer binder improved the strength of the clays. However, wet curing at $\mathrm{OMC}$ and at $25^{\circ} \mathrm{C}$ led to reduction in strength following reduction in $\mathrm{pH}$ due to the inability of residual water to evaporate which led to dilution and retardation in dissociation of the Al-Si units. It was observed that optimum performance of volcanic ash geopolymer in stabilisation can be obtained under dry conditions which increases the $\mathrm{pH}$ of the gel and facilitates dissociation and polycondensation. Table 3 is a summary of the key findings from the reviewed literature. 
Table 3. Key Parameters of Geopolymer Stabilised Clays from Reviewed Literatures.

\begin{tabular}{|c|c|c|c|c|c|c|c|}
\hline Soil Type & Precursor & $\begin{array}{l}\text { Precursor (wt. \% } \\
\text { of Soil) }\end{array}$ & Alkali Activator & Molarity & $\begin{array}{l}\text { Curing Temp. } \\
\left({ }^{\circ} \mathrm{C}\right)\end{array}$ & Reference & Remarks \\
\hline soft marine clay & PFA (Class F) & $25-45$ & $\begin{array}{l}\mathrm{NaOH} \text { and } \\
\mathrm{Na}_{2} \mathrm{SiO}_{3}\end{array}$ & $3-18$ & 25 and 40 & {$[27]$} & Improvement UCS \\
\hline Silt & $\begin{array}{l}\text { PFA (Class F) } \\
\text { and GGBS }\end{array}$ & $20-30$ & $\begin{array}{l}\mathrm{NaOH} \text { and } \\
\mathrm{Na}_{2} \mathrm{SiO}_{3}\end{array}$ & 8 & & [46] & $\begin{array}{l}\text { Improved permeability } \\
\text { and UCS }\end{array}$ \\
\hline Lateritic soil & PFA (Class C) & NR & $\begin{array}{l}\mathrm{NaOH} \text { and } \\
\mathrm{Na}_{2} \mathrm{SiO}_{3}\end{array}$ & $4.5-5.8$ & Ambient & {$[64]$} & Improved UCS \\
\hline Lean clay & $\mathrm{Mk}$ & $3-15$ & $\begin{array}{l}\mathrm{NaOH} \text { and } \\
\mathrm{Na}_{2} \mathrm{SiO}_{3}\end{array}$ & NR & Ambient & [53] & $\begin{array}{l}\text { Increased strength with } \\
\text { no increase in MDD }\end{array}$ \\
\hline soft soil & PFA (Class F) & $20-50$ & $\begin{array}{l}\mathrm{NaOH} \text { and } \\
\mathrm{Na}_{2} \mathrm{SiO}_{3}\end{array}$ & $10-15$ & Ambient & [44] & Increased UCS \\
\hline Silty clay & PFA (Class F) & 30 & $\begin{array}{l}\mathrm{NaOH} \text { and } \\
\mathrm{Na}_{2} \mathrm{SiO}_{3}\end{array}$ & 10 & 65,75 , and 85 & [45] & Increased UCS \\
\hline $\begin{array}{l}\text { High plasticity } \\
\text { clay }\end{array}$ & $\begin{array}{c}\text { GGBS and } \\
\text { Phosphogypsum }\end{array}$ & $6-30$ & $\mathrm{NaOH}$ & NR & Ambient & [57] & Increased shear strength \\
\hline Kaolin clay & $\begin{array}{l}\text { PFA (Class C } \\
\text { and F) }\end{array}$ & 20 and 40 & $\mathrm{Na}_{2} \mathrm{OSiO}_{2}$ & NR & Ambient & [39] & $\begin{array}{l}\text { Reduced volume } \\
\text { compressibility }\end{array}$ \\
\hline Silty clay & PFA (Class C) & $\begin{array}{c}0,5,10,15 \text {, and } \\
20\end{array}$ & $\begin{array}{c}\mathrm{Na}_{2} \mathrm{SiO}_{3} \text { and } \\
\mathrm{CCR}\end{array}$ & $\begin{array}{c}\mathrm{Na}_{2} \mathrm{SiO}_{3} / \text { water } \\
\text { ratio }(0.2,0.6,1 \\
\text { and } 1.4) \mathrm{CCR} \text { of } \\
7 \%\end{array}$ & Ambient & [47] & $\begin{array}{c}\text { Reduced PI, increase in } \\
\text { UCS }\end{array}$ \\
\hline Kaolin clay & PFA (Class C) & 100,50 , and 20 & $\mathrm{Na}_{2} \mathrm{SiO}_{3}$ & NR & Ambient & [48] & $\begin{array}{l}\text { Increased UCS. High } \\
\text { calcium content } \\
\text { reduced long-term } \\
\text { strength }\end{array}$ \\
\hline $\begin{array}{l}\text { Low plasticity } \\
\text { clays }\end{array}$ & $\begin{array}{l}\text { GGBS, PFA, MK, } \\
\text { MP, GP, RHA, } \\
\text { and SF }\end{array}$ & 10 to 20 & $\begin{array}{l}\mathrm{NaOH} \text { and } \\
\mathrm{Na}_{2} \mathrm{SiO}_{3}\end{array}$ & $\begin{array}{c}8,10,14,12 \text {, and } \\
16\end{array}$ & $\begin{array}{c}\text { Initially at } \\
\text { ambient and } \\
\text { later freeze dried }\end{array}$ & {$[41]$} & Increased UCS \\
\hline Kaolin clay & $\begin{array}{l}\text { PFA (Class F) } \\
\text { and GGBS }\end{array}$ & 10 and 20 & $\begin{array}{l}\mathrm{NaOH} \text { and } \\
\mathrm{Na}_{2} \mathrm{SiO}_{3}\end{array}$ & 14 & Ambient & [42] & $\begin{array}{l}\text { Improved MDD, } \\
\text { Improved yield strength } \\
\text { under cyclic loading, } \\
\text { higher durability. }\end{array}$ \\
\hline $\begin{array}{l}\text { high and low } \\
\text { plasticity clays }\end{array}$ & $\begin{array}{l}\text { PFA (Class F) } \\
\text { and GGBS }\end{array}$ & 10 and 20 & $\begin{array}{l}\mathrm{NaOH} \text { and } \\
\mathrm{Na}_{2} \mathrm{SiO}_{3}\end{array}$ & & Ambient & [49] & $\begin{array}{l}\text { Improved yield } \\
\text { strength. }\end{array}$ \\
\hline Clay & GP & $3-25 \%$ & $\mathrm{NaOH}$ & $1-8$ & $25-70$ & [58] & Improved UCS \\
\hline Clay & POFA & $15-20 \%$ & $\mathrm{KOH}$ & 10,12 & $\begin{array}{c}\text { Ambient, 50, and } \\
100\end{array}$ & {$[63]$} & $\begin{array}{l}\text { Improved UCS. Higher } \\
\text { UCS with increased } \\
\text { temperature. }\end{array}$ \\
\hline Clay & GP & $3-20 \%$ & CCR & $\begin{array}{l}4-13 \% \text { CCR by } \\
\text { mass of dry soil }\end{array}$ & $25^{\circ} \mathrm{C}$ and $70^{\circ} \mathrm{C}$ & [59] & $\begin{array}{c}\text { Increased UCS. UCS } \\
\text { increased with } \\
\text { temperatures. }\end{array}$ \\
\hline Clay & $\begin{array}{l}\text { PFA (class } C \text { and } \\
\text { F) }\end{array}$ & 10 and $20 \%$ & $\begin{array}{l}\mathrm{NaOH} \text { and } \\
\mathrm{Na}_{2} \mathrm{SiO}_{3}\end{array}$ & 10 & Ambient & [50] & $\begin{array}{l}\text { Improved UCS. Higher } \\
\text { UCS values for Class F } \\
\text { geopolymer treated } \\
\text { samples }\end{array}$ \\
\hline Clay & VA & $0,5,10$, and 15 & $\mathrm{NaOH}$ & 4,8 , and 12 & 40 & {$[40]$} & \\
\hline $\begin{array}{l}\text { High Plasticity } \\
\text { Clay }\end{array}$ & MK and OPC & 30 & $\begin{array}{l}\mathrm{NaOH} \text { and } \\
\mathrm{Na}_{2} \mathrm{SiO}_{3}\end{array}$ & 1.9 and 3.2 & Ambient & [54] & $\begin{array}{l}\text { Increased UCS. } \\
\text { Reduced porosity }\end{array}$ \\
\hline $\begin{array}{l}\text { High Plasticity } \\
\text { Clay }\end{array}$ & MK & 4,10, and 15 & $\begin{array}{l}\mathrm{KOH} \text {, Silica } \\
\text { fume and } \mathrm{H}_{2} \mathrm{O}\end{array}$ & - & Ambient, $22^{\circ} \mathrm{C}$ & [55] & $\begin{array}{l}\text { Increased UCS. } \\
\text { Reduced } \\
\text { compressibility, swell, } \\
\text { and shrinkage }\end{array}$ \\
\hline $\begin{array}{l}\text { Low plasticity } \\
\text { clays }\end{array}$ & PFA (Class F) & 10,20 , and 30 & $\mathrm{NaOH}$ and $\mathrm{KOH}$ & 8,10, and 12 & Ambient & [52] & $\begin{array}{l}\text { Increased UCS. } \\
\text { Reduced collapse } \\
\text { potential, and } \\
\text { permeability. }\end{array}$ \\
\hline $\begin{array}{l}\text { High plasticity } \\
\text { clay }\end{array}$ & $\begin{array}{l}\text { GGBS and PFA } \\
\text { (Class F) }\end{array}$ & $\begin{array}{c}\text { GGBS }(4-50 \%) \\
\text { and PFA }(4-20 \%)\end{array}$ & $\begin{array}{l}\mathrm{NaOH} \text { and } \\
\mathrm{Na}_{2} \mathrm{SiO}_{3}\end{array}$ & $4-14.5$ & $\begin{array}{l}\text { Under water } \\
\text { curing }\end{array}$ & [24] & Increased UCS \\
\hline Clay & MK & $6-12$ & $\begin{array}{l}\mathrm{CaO} \text { and } \\
\mathrm{NaHCO}_{3}\end{array}$ & $3-11$ & 5 & [56] & $\begin{array}{c}\text { Improved UCS. } \\
\text { Strength reduction after } \\
\text { optimum activator } \\
\text { content }\end{array}$ \\
\hline $\begin{array}{l}\text { High plasticity } \\
\text { clay }\end{array}$ & Class F PFA & 0.3 & $\begin{array}{l}\mathrm{NaOH} \text { and } \\
\mathrm{Na}_{2} \mathrm{SiO}_{3}\end{array}$ & 10 & $27-75$ & [16] & \\
\hline
\end{tabular}




\section{Discussions}

\subsection{UCS of Geopolymer Stabilised Clay}

The suitability of a given soil for stabilisation with OPC will vary depending on if the soil is granular or clay. For granular materials, it is required that the soil be well graded. Gap graded and poorly graded soils have been reported to consume uneconomical amounts of OPC in order to fill up the pores in the soil mass and bond soil particles. On the other hand, for clays, the percentage and the plasticity of the fines portion are controlling factors. As stated in [65], cement treated clays with LL greater than $40 \%$ and plastic limits greater than $20 \%$ present difficulties in achieving good in-place mixing of the cement with the soils and may lead to uneven distribution of additives with subsequent non-uniform strength development. For geopolymer treatment, the high plasticity clays may result in uneconomical amounts of precursor and activator liquid required to improve the strength of the clays in practical applications. Field trials are imperative in this regard. Furthermore, the suitability of cement stabilised materials as pavement subgrade materials is dependent on meeting minimum strength values. Therefore, it is important to consider the effectiveness of geopolymer-stabilised clays based on their performance with reference to the requirement for stabilised materials for pavement applications. Here, a minimum 7-day UCS value for cylindrical soil samples specified by [65] and given in Table 4 is used. The UCS values are considered since it is deemed as a closer representative of the strength performance for stabilised materials [60].

Table 4. 7-days Minimum UCS for Practical Application [65].

\begin{tabular}{cc}
\hline Application & UCS (kPa) \\
\hline Base layer (FP) & 5160 \\
\hline Subbase layer (FP) & 1720 \\
\hline Subbase layer (RP) & 1380 \\
\hline Lower layers in high embankments (FP) & 500 \\
\hline Lower layers in high embankments (RP) & 1000 \\
\hline FP-flexible pavement, RP-rigid pavement.
\end{tabular}

The UCS results of geopolymer stabilised clays from some of the reviewed articles are plotted in Figures 8-10. The stabilised soils are labelled to indicate the binder type and content and the molarity of the alkaline solution following the format reported in [66] and [67].

The stabilised soils have all been treated with sodium silicate and sodium hydroxide alkaline activator liquids. For example, the sample labelled C $+25 \%$ FAC $+3 \mathrm{M}$ denotes clay stabilised with $25 \%$ class C PFA and a mixture of sodium silicate and sodium hydroxide with a molarity of 3 . From Figures 8-10, it can be seen that increasing the PFA content and molarity of the activator liquid improves the 7-day UCS. An important observation is that the samples treated with class F PFA like C $+25 \% \mathrm{FAF}+3 \mathrm{M}, \mathrm{C}+35 \% \mathrm{FAF}+3 \mathrm{M}, \mathrm{C}+25 \%$ $\mathrm{FAF}+12 \mathrm{M}$, and $\mathrm{C}+35 \% \mathrm{FAF}+12 \mathrm{M}$ had lower 7-days UCS. The lower strength values can be related to the slow strength gain of the geopolymer binder at room temperature curing. The slow reaction is seen even with increased molarity of the activator. This because even though a high molarity of $\mathrm{NaOH}$ will dissociate more Al-Si units in solution, the process of gelation, realignment, and polycondensation at room temperature will take longer. Hence, short term strength is lower compared to the class C PFA geopolymers. Samples stabilised with more calcium content such as GGBS can easily meet 7-day UCS requirement compared with class F PFA geopolymers because of the calcium-based binders which precipitate and harden more rapidly than the N-A-S-H binders. For example, $\mathrm{C}+5 \% \mathrm{FAF}+15 \%$ GGBS $+8 \mathrm{M}$ and $\mathrm{C}+20 \% \mathrm{GGBS}+8 \mathrm{M}$ performed better in relation to the [65] than C $+10 \%$ FAF $+10 \%$ GGBS $+8 \mathrm{M}$ with the same molarity. Moreover, class C PFA geopolymer due to increased calcium contents easily meet 7-days UCS requirements. The early strength requirements of PFA based geopolymers can be significantly improved using other sources 
with increased calcium content such as CCR. As seen in Figure 9, C + 30\% FAC $+10 \%$ CCR $+5 \mathrm{M}$ with $30 \%$ PFA and $10 \%$ CCR is observed to have higher strength than C $+30 \%$ FAC $+5 \mathrm{M}$. The combination of PFA and GGBS proves to be a better combination both for short-term (7-days) and long-term strength development. Furthermore, from Figure 8, RHA-GGBS blends showed good early strength gain which reinforces profitable use of the waste material. The strength of RHA-GGBS blends as in C + 4\% RHA + 16\% GGBS + $12 \mathrm{M}$ is $5000 \mathrm{kPa}$ which exceeds C $+2 \%$ RHA $+18 \%$ GGBS $+12 \mathrm{M}$ at $4000 \mathrm{kPa}$ for same molarity of alkaline activator. Moreover, from Figure 10, metakaolin blended geopolymer stabilised samples showed increased strength when blended with GGBS. However, comparing $\mathrm{C}+2.5 \% \mathrm{MK}+17.5 \% \mathrm{GGBS}+12 \mathrm{M}$ and $\mathrm{C}+5 \% \mathrm{MK}+15 \% \mathrm{GGBS}+12 \mathrm{M}$, it is easily seen that $2.5 \%$ metakaolin content works better than $5 \%$ in terms of early strength gain. As expected, the highly reactive metakaolin with higher alumina and silica content will take longer to develop its optimum strength based on room temperature curing.

\section{Performance of Geopolymer Stabilised Clays}

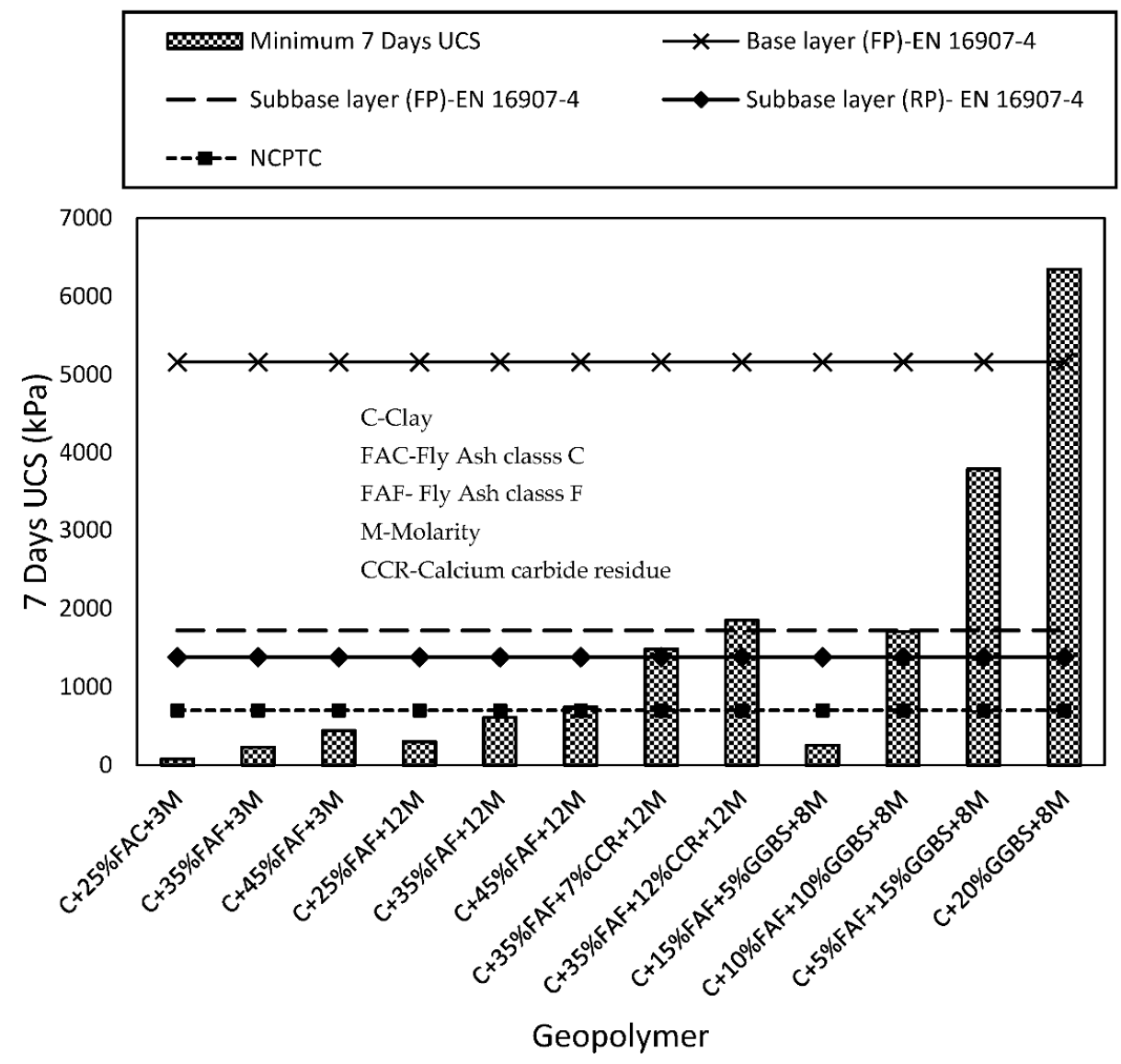

Figure 8. 7 days UCS of Geopolymer Stabilised Clays with Various Kinds of Geopolymers.

The stabilised clays showed promising use as subbase materials. However, the performance of GP geopolymers were below the minimum for subbase application. The low strength of GP geopolymers may be attributed to the lower alumina content which can affect the Al-Si chains. Comparing the strength of the treated soils to the average UCS for cement stabilised subgrade materials as specified by National Concrete Pavement Technology Centre, Iowa State University, it can be seen from Figures 8-10 that most of the stabilised clays meet the minimum requirement to be utilised as subgrade material. Stabilised subgrade materials are useful in optimizing pavement thickness, increasing life span of concrete pavements, and improving the bearing capacity of the material under slabs and foundation elements [68]. Overall, geopolymers can be utilised as alternative 
binders for soil stabilisation for road subgrade and subbase applications due to their high strength, low carbon footprint and the alternative use of agricultural and industrial waste recycling they offer.

\section{Performance of Geopolymer Stabilised Clays}

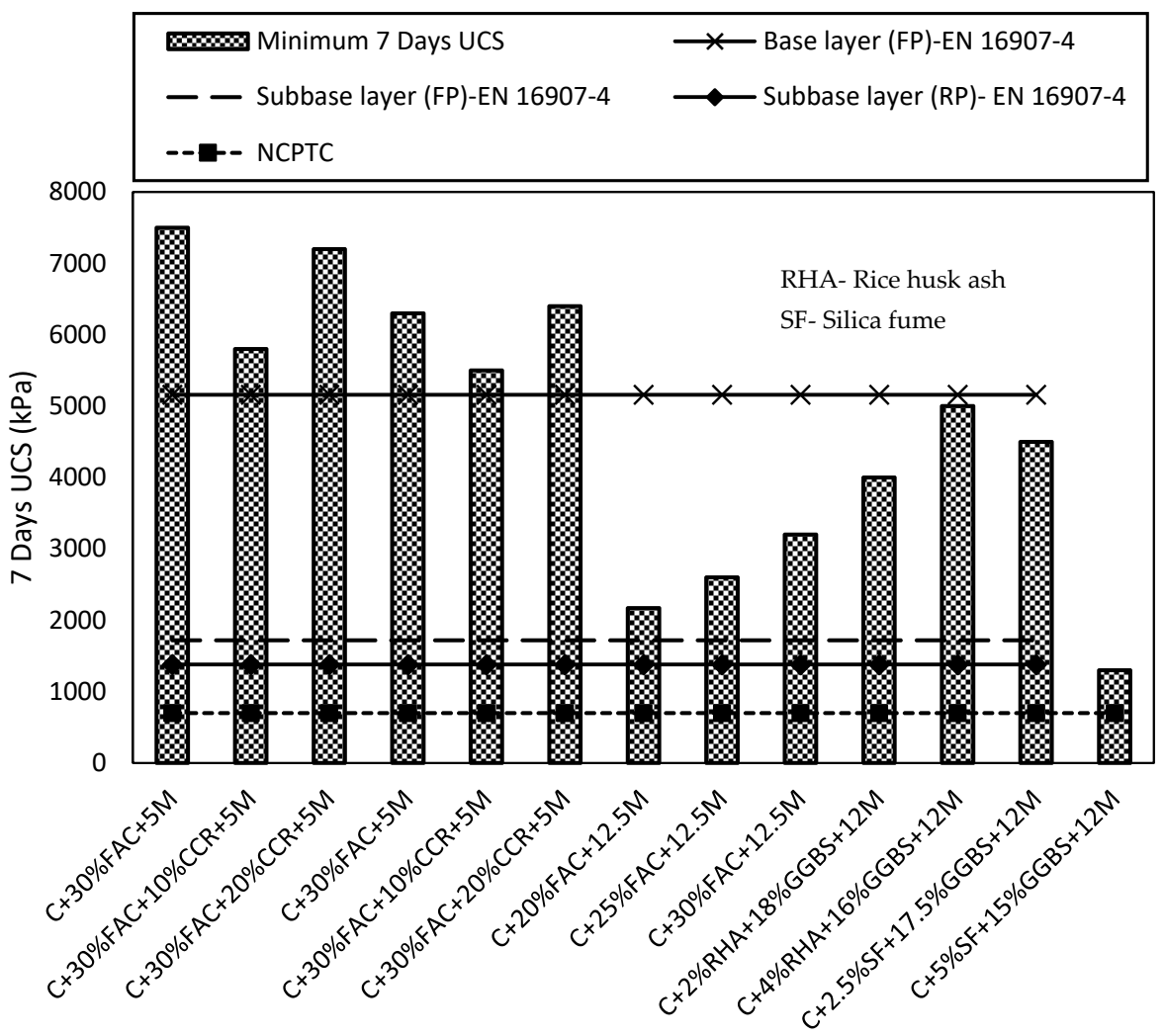

Geopolymer

Figure 9. 7 days UCS of Geopolymer Stabilised Clays with Various Kinds of Geopolymers.

\subsection{Effects of Alkali Activator Type on Microstructure and Strength of Geopolymers Binders}

The alkali reagents play a major role in influencing the performance of geopolymer stabilised clays by affecting both the rate of the reaction and the type of cementitious products available to bind soil particles. This has a direct impact on the strength development and durability [69]. A study by [70] showed that water content and sodium silicate content both influenced the nature of the alkali solution and had significant effects on the compressive strength of fly ash-based geopolymer. The strength of the geopolymer increased with increasing water content and $\mathrm{Na}_{2} \mathrm{SiO}_{3}$ until an optimum value was attained. $\mathrm{Na}$ or $\mathrm{K}$-based alkali solutions are reported to have distinct effects on the characteristics of the resulting geopolymers. In the study by [71], Na and K-based alkali activators were utilised with MK in geopolymerisation. The results of the study showed higher performance of the K-based solution over the Na-based alternative. This enhanced performance can be linked to the larger size of K-ion which in the geopolymer matrix results in increased electrochemical balance in the $\mathrm{Si}-\mathrm{Al}$ chains with increasing $\mathrm{Si} / \mathrm{Al}$ content of the precursor and was more profound between $1.4 \leq \mathrm{Si} / \mathrm{Al} \leq 1.9$. As shown in the SEM results in Figure 11 below, higher density due to reduced porosity is observed for MK activated with K-based activator over Na-based alkali activated MK. This can be linked to the fact that during synthesis of the gel, more minute water molecules will be attracted to the sites of the cations forming a sort of nucleation point for crystallisation. As is already well-known, the formation of polymeric chains would also involve bonding with $\mathrm{OH}$ anions on the surface of undissolved waste particles in the precursor, which is also determined by the cations present. 


\section{Performance of Geopolymer Stabilised Clays}

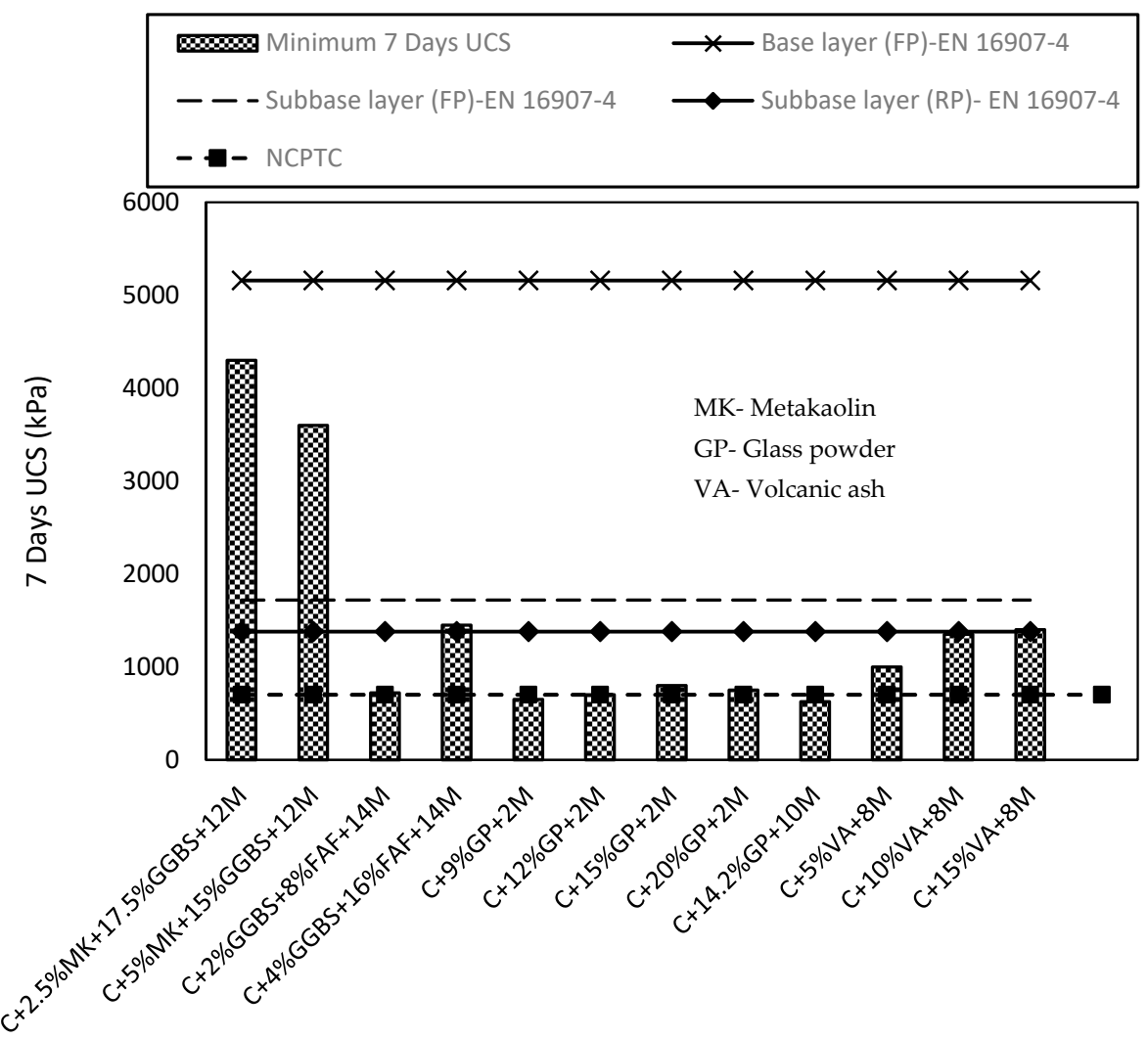

Geopolymer

Figure 10. 7 days UCS of Geopolymer Stabilised Clays with Various Kinds of Geopolymers.
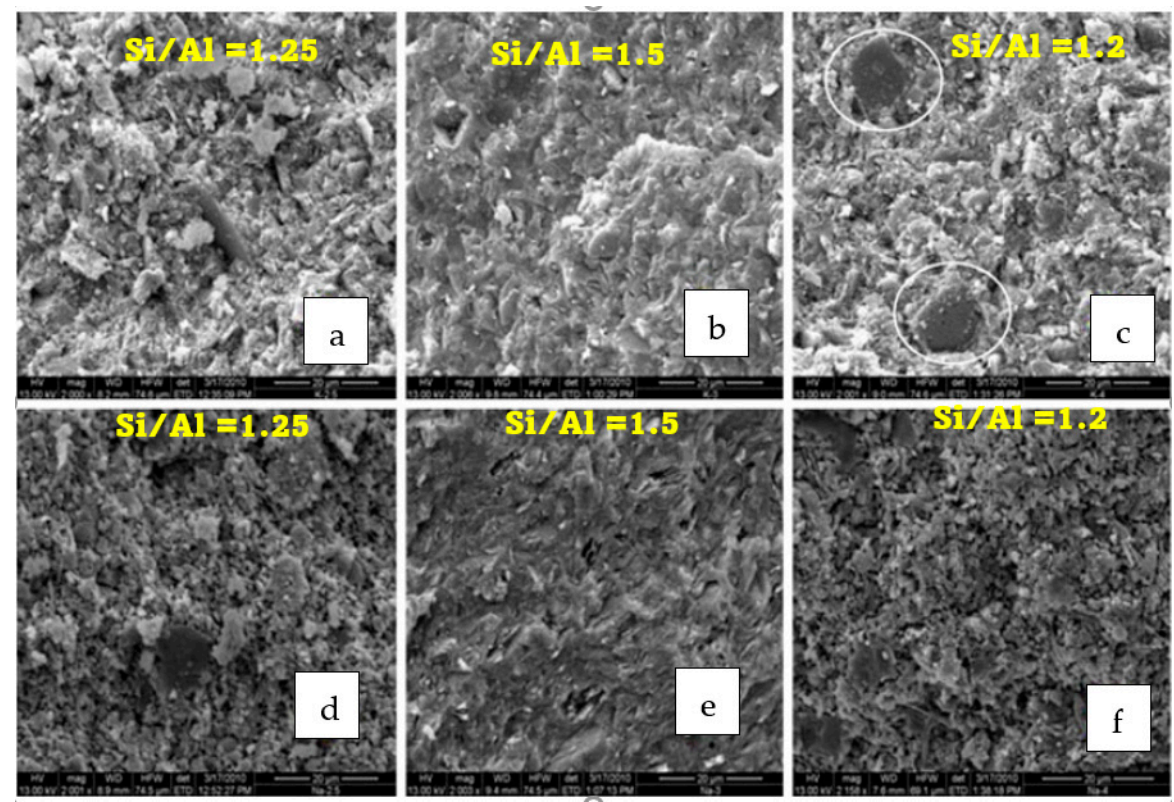

Figure 11. SEM results of K and Na Activated MK Geopolymers [71]. (a-c) K-activated MK (d-f) Naactivated MK.

As earlier mentioned, the larger K-ions can coordinate with more water molecules or $\mathrm{OH}$ groups which increases the amount of $\mathrm{Si}-\mathrm{Al}$ at such nucleation points and supports further structural development $[69,72]$. Furthermore, a faster rate of geopolymerisation has been reported for Na-based activator and is reported to be linked to the smaller 
sized Na-cation with increased specific surface area over K-cation [72]. However, in the experimental work by [69], using PFA from various sources, it was observed that some of the fresh geopolymer pastes showed faster setting with $\mathrm{NaOH}$ while other showed faster setting rate with $\mathrm{KOH}$. In terms of the amount of dissociated $\mathrm{Al}$ and Si available for polymerisation upon mixing with an activator, it has been reported that $\mathrm{NaOH}$ and $\mathrm{KOH}$ showed significant difference which directly influences the structure of the resulting geopolymer. In addition, the compressive strength of alkali activated by-product materials is significantly influenced by the type of alkali earth metal ions utilised in the mixture. Considering $\mathrm{Na}$ and $\mathrm{K}$ ions, it is observed that the use of $\mathrm{K}$-based solution results in increased compressive strength due to the attraction of more $\mathrm{Si}-\mathrm{Al}$ species and increased nucleation with improved structural development and performance over Na-based systems. Moreover, the presence of sodium silicates or potassium silicate in the system has additional impact on the structural performance and influences the compressive strength. Potassium silicate is reported to yield more stable structures than sodium silicates. This again is in line with previous findings by [73], that for a given fixed ration of $\mathrm{M}_{2} \mathrm{O} / \mathrm{SiO}_{2}$ ratio (where $\mathrm{M}$ is the alkali metal), potassium silicate-based geopolymer structure showed a more strongly held composition of the aluminosilicate species than for sodium silicate-based configuration. Figure 12 compares the compressive strength of clay-PFA geopolymer mixtures constituted with a combination of different ratios of $\mathrm{NaOH}$ and $\mathrm{KOH}$ with sodium silicate and shows that the compressive strength of the geopolymers increased with increasing $\mathrm{K}_{2} \mathrm{O} / \mathrm{Na}_{2} \mathrm{O}$ ratio. In addition, the addition of promoters such as $\mathrm{MgO}$ and $\mathrm{CaO}$ are known to expedite geopolymerisation rates and enhance compressive strength of resulting stabilised clays as reported in [74].

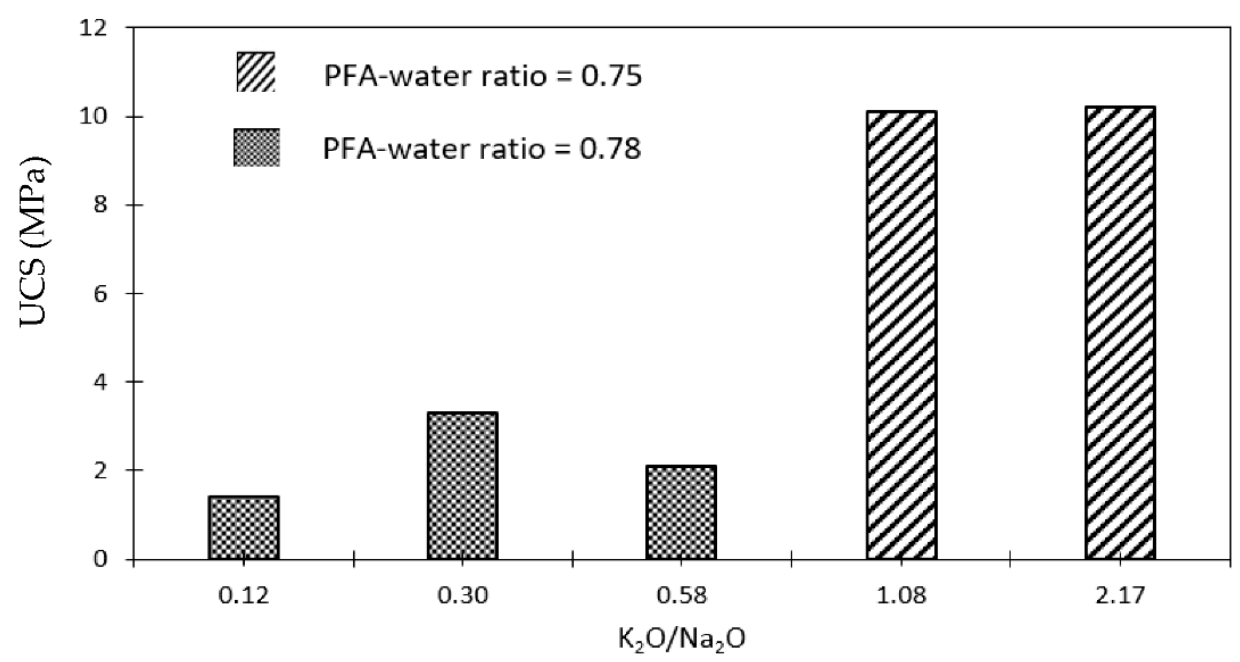

Figure 12. Effects of $\mathrm{K}_{2} \mathrm{O} / \mathrm{Na}_{2} \mathrm{O}$ ratio of Alkali Activator on Compressive Strength of PFA-Clay Geopolymer Mixtures.

The microstructure of cement and lime stabilised soils are usually characterised with the flaky crystals of CSH from the formation of cementitious paste which coats and binds the soil particles, filling up voids and increasing bond strength as reported by [75] and shown in Figure 13a. However, with sulphate presence, cement and lime treated clays may also show expansive ettringite crystals within interparticle spaces which can induce expansion and increase porosity as shown in Figure 13b. Geopolymers, apart from their eco-friendliness, perhaps have the extra advantage of reduced ettringite formation due to lower calcium requirement and may be more effective in reducing sulphate induced expansion synonymous with cement-lime treated sulphate bearing clays. In terms of the morphology, geopolymer stabilised clays have been reported to show relatively dense matrixes which gives improved strength and their ability to immobilise heavy metals in wastes. SEM results of previous studies show that the workability of the geopolymer binders is influenced by the particle size and shape of the precursor which may also 
influence the performance of the binder. The study by [76] considered the morphology of two types of PFA geopolymers and reported that PFAs with more rounded particles showed improved workability at a lower activator liquid-PFA ratio due to the shape of the PFA grains. This cenospherical particle shape enhances the ball bearing effect which allows easy mixing of soils and may have resultant effect on the strength of the stabilised soils. In addition, the presence of alkaline liquid causes cracks and holes on the PFA particles, which in turn causes cementitious products to form within the spheres and further enhances the density and reduces porosity as reported in [27] and shown in Figure 13c. Microstructural characteristic of 7-days and 28-days cured PFA stabilised clays supports the premise that increasing geopolymer binder content and curing duration enhances the homogeneity of the fabric of stabilised soils. A comparison between untreated and geopolymer treated samples showed more profound interparticle connections resulting in a denser matrix. However, at higher precursor contents, unreacted waste particles may lead to higher porosity due to increased internal surface area.

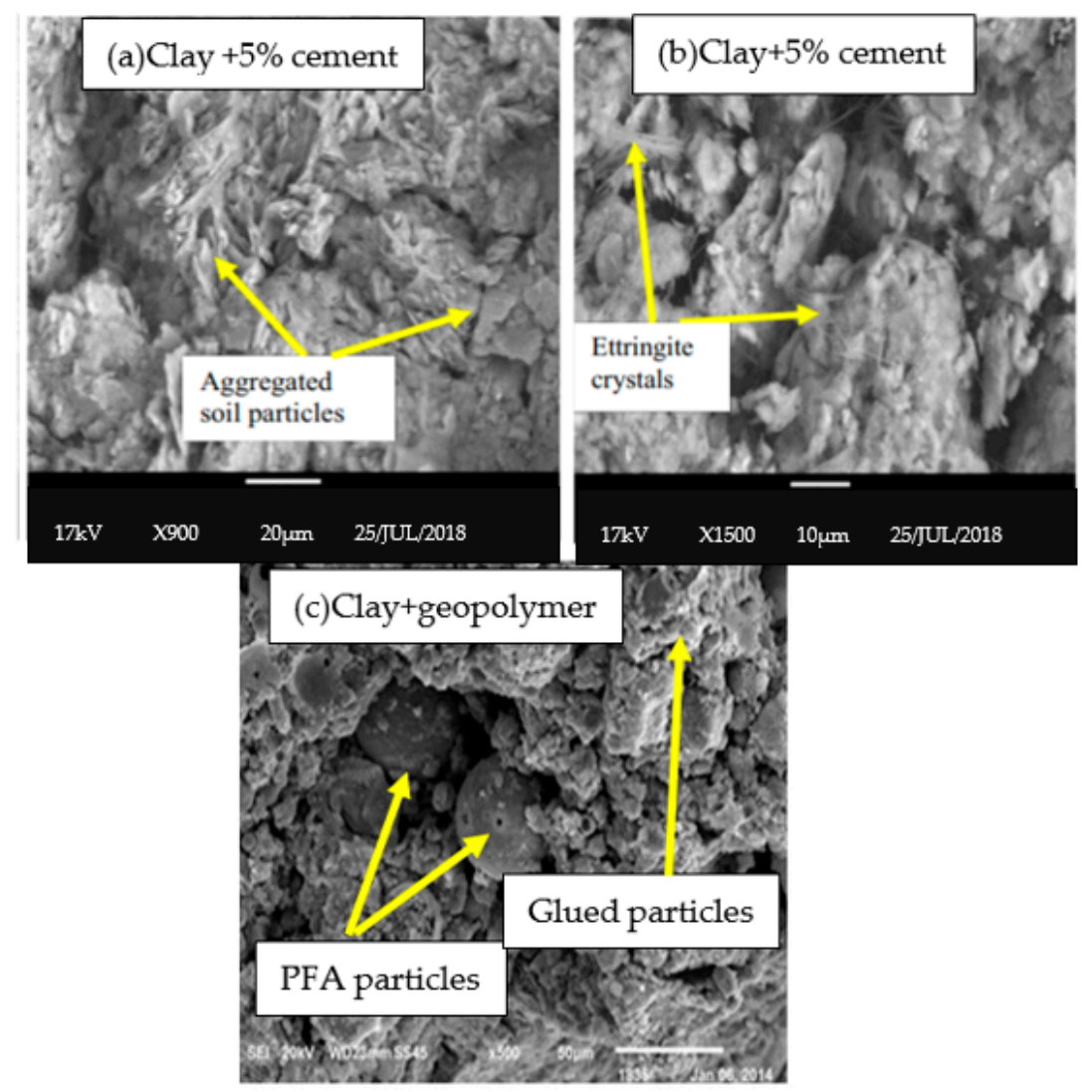

Figure 13. SEM of Stabilised Clays (a) 5\% Cement-stabilised Clay (b) 5\% Cement-stabilised Clays Showing Ettringite Crystals [75] (c) PFA Stabilised Clay [76].

\subsection{Durability of Geopolymers Stabilised Clays}

Apart from the strength performance of stabilised soils, durability is often a concern as stabilised materials may easily lose their cementation under rapid moisture and temperature variations which is characteristic of current climatic conditions. However, geopolymer stabilised clays have shown reasonably fair performance in this regard. Durability test performed on PFA-GGBS stabilised clays by [77] showed that the geopolymer content required for sustained stability under wet-dry cycles and freeze-thaw conditions is higher than that required to meet strength requirements. It was observed that increasing geopolymer content beyond strength requirement led to improved resistance to volume changes caused by wet-dry and freeze-thaw cycles as expected. Early age cured samples under wetting and drying cycles can suffer significant loss of bond due to the excess water within the 
clay-geopolymer mixture during wetting and may impede bond development leading to breakdown of the soil structure. On the other hand, higher temperatures during drying can lead to significant loss of vital moisture which can also slow down the geopolymerisation process and lead to weaker bonds with eventual collapse of the structure. Hence, sufficient binder content and curing are vital to the performance of the stabilised clays in order to catch up with cement stabilised counterparts. While this is feasible, the economic concern would need to be evaluated under site-specific circumstances. The capability of geopolymer stabilised clays to resist sulphate effects has been highlighted by [78] by measuring mass loss following soaking of lightweight GGBS geopolymer stabilised clays. From their conclusion, the geopolymer stabilised clays exhibited a high level of resistance to sulphate attack under various periods of soaking. In a separate study, reference [79] compared the performance of lithomarge-based geopolymers mortars and OPC mortars in resisting sodium sulphate and hydrochloric acid attacks. The results of the study showed that the geopolymer mortars were least affected by the sulphate and acid attack when compared to the OPC mortars. Whereas experimental OPC mortars show visible micro-cracks on soak samples, soaked geopolymer samples showed no sign of cracks after soaking for same duration. The results agree with [80] in which PFA geopolymers and OPC mortars were soaked in $\mathrm{Mg}_{2} \mathrm{SO}_{4}$ for up to 150 days to compare the performance of the geopolymer and OPC samples. It was observed that geopolymer samples showed no surface defects after the soaking period while OPC samples were observed to have deteriorated with visible surface cracks. The results of these studies are reference points in buttressing the effectiveness of geopolymer stabilised clays under aggressive environmental conditions.

\section{Conclusions}

Geopolymers can be reliably employed in the improvement of the engineering properties of weak clays with results comparable to traditional stabilisation methods involving the use of cement and lime. The advantage of low carbon emission and energy consumptionwhich are synonymous with the use of geopolymers-are undoubtedly desirable and put them ahead of cement and lime stabilisation in the face of the current heightened demand for greener methods. Activation of this Al-Si rich industrial waste has been accomplished with sodium hydroxide and sodium silicate mixtures and is found to be the most utilised solution for geopolymerisation. The molarity of the alkaline activator and the ratio of the activator to geopolymer precursor content are significant factors determining the strength of the stabilised clays. Although elevated curing of geopolymer stabilised soils increases the reaction rate and strength of the treated soils, The current findings also show promising use of the technique in practical applications such as subbase and subgrade materials for road pavement, slabs, and foundation elements. However, the use of geopolymer as a binder in soil stabilisation is still emerging and requires practical field application to evaluate the performance of stabilised clays under field conditions. For example, the performance of clays stabilised with geopolymers under cyclic loading conditions which is representative of actual response on highway subgrade material is yet to be adequately investigated. The need for geopolymer stabilised soils to be subjected to durability test simulated by wet-dry cycles to evaluate their viability under flooded conditions and also swell tests of geopolymer stabilised sulphate bearing expansive clays is required.

Author Contributions: Conceptualization, J.J.J. and S.J.A.; methodology, J.J.J. and S.J.A.; software, J.J.J. and S.J.A.; validation, J.J.J. and S.J.A.; formal analysis, J.J.J. and S.J.A.; investigation, J.J.J.; resources, S.J.A.; data curation, J.J.J.; writing—original draft preparation, J.J.J.; writing-review and editing, J.J.J., S.J.A., C.A.B., A.K.; visualization, S.J.A., C.A.B., A.K.; supervision, S.J.A., C.A.B., A.K.; project administration, S.J.A., C.A.B., A.K. All authors have read and agreed to the published version of the manuscript.

Funding: This research received no external funding.

Institutional Review Board Statement: Not applicable.

Informed Consent Statement: Not applicable. 
Data Availability Statement: Some or all data that support the findings of this study are available from the corresponding author.

Acknowledgments: The lead author is thankful to the Ph.D. supervisory team for their enormous support during this study.

Conflicts of Interest: The authors declare no conflict of interest.

\section{References}

1. Abdullah, H.H.; Shahin, M.A.; Walske, M.L. Review of Fly-Ash-Based Geopolymers for Soil Stabilisation with Special Reference to Clay. Geosciences 2020, 10, 249. [CrossRef]

2. Ayeldeen, M.; Hara, Y.; Kitazume, M.; Negm, A. Unconfined Compressive Strength of Compacted Disturbed Cement-Stabilized Soft Clay. Int. J. Geosynth. Ground Eng. 2016, 2, 28. [CrossRef]

3. Pongsivasathit, S.; Horpibulsuk, S.; Piyaphipat, S. Assessment of mechanical properties of cement stabilized soils. Case Stud. Constr. Mater. 2019, 11, e00301. [CrossRef]

4. Horpibulsuk, S.K.; Rachan, R.L.; Chinkulkijniwat, A.; Raksachon, Y.; Suddeepong, A. Analysis of strength development in cement-stabilized silty clay from microstructural considerations. Constr. Build. Mater. 2010, 24, 2011-2021. [CrossRef]

5. Miyazaki, Y. A Study of Cement Treating Dredged Clay and under-Water Casting Method. Ph.D. Thesis, Kyushu University, Fukuoka, Japan, 2003.

6. Journals, I.; Muhmed, A.; Wanatowski, D. Effect of Lime Stabilisation on the Strength and Microstructure of Clay. IOSR J. Mech. Civil Eng. (IOSR-JMCE) 2013, 6, 87-94.

7. Baldovino, J.A.; Moreira, E.B.; Teixeira, W.; Izzo, R.L.; Rose, J.L. Effects of lime addition on geotechnical properties of sedimentary soil in Curitiba, Brazil. J. Rock Mech. Geotech. Eng. 2018, 10, 188-194. [CrossRef]

8. Ghobadi, M.H.; Abdilor, Y.; Babazadeh, R. Stabilization of clay soils using lime and effect of $\mathrm{pH}$ variations on shear strength parameters. Bull. Int. Assoc. Eng. Geol. 2014, 73, 611-619. [CrossRef]

9. Abbey, S.J.; Ngambi, S.; Coakley, E. Effect of cement and by-product material inclusion on plasticity of deep mixing im-proved soils. Int. J. Civil Eng. Technol. 2016, 7, 265-274.

10. Abbey, S.J.; Ngambi, S.; Ganjian, E. Development of strength models for prediction of unconfined compressive strength of cement/by-product material improved soils. Geotech. Test J. 2017, 40, 928-935. [CrossRef]

11. Abbey, S.J.; Eyo, E.U.; Oti, J.; Amakye, S.Y.; Ngambi, S. Mechanical Properties and Microstructure of Fibre-Reinforced Clay Blended with By-Product Cementitious Materials. Geosciences 2020, 10, 241. [CrossRef]

12. Abbey, S.J.; Ngambi, S.; Olubanwo, A.O.; Tetteh, F.K. Strength and Hydraulic Conductivity of Cement and By-Product Cementitious Materials Improved Soil. Int. J. Appl. Eng. Res. 2018, 13, 8684-8694.

13. Eyo, E.U.; Ng'Ambi, S.; Abbey, S.J. Performance of clay stabilized by cementitious materials and inclusion of zeo-lite/alkaline metals-based additive. Transp. Geotech. 2020, 23, 100330. [CrossRef]

14. Jeremiah, J.J.; Abbey, S.J.; Booth, C.A.; Kashyap, A. Results of Application of Artificial Neural Networks in Predicting GeoMechanical Properties of Stabilised Clays-A Review. Geotechnics 2021, 1, 8. [CrossRef]

15. Pourakbar, S.; Huat, B.K. A review of alternatives traditional cementitious binders for engineering improvement of soils. Int. J. Geotech. Eng. 2016, 11, 1-11. [CrossRef]

16. Horpibulsuk, S.; Phetchuay, C.; Chinkulkijniwat, A.; Cholaphatsorn, A. Strength development in silty clay stabilized with calcium carbide residue and fly ash. Soils Found. 2013, 53, 477-486. [CrossRef]

17. Wong, B.Y.F.; Wong, K.S.; Phang, I.R.K. A review on geopolymerisation in soil stabilization. IOP Conf. Series: Mater. Sci. Eng. 2019, 495, 012070. [CrossRef]

18. Andrew, R.M. Global $\mathrm{CO}_{2}$ emissions from cement production, 1928-2018. Earth Syst. Sci. Data 2019, 11, 1675-1710. [CrossRef]

19. Khale, D.; Chaudhary, R. Mechanism of geopolymerization and factors influencing its development: A review. J. Mater. Sci. 2007, 42, 729-746. [CrossRef]

20. Davidovits, J. Solid phase synthesis of a mineral block polymer by low temperature polycondensation of alumino-silicate polymers. In Proceedings of the IUPAC International Symposium on Macromolecules, The Royal Institute of Technology, Stockholm, Sweden, 30 August-1 September 1976. Stockholm, Topic III, New Polymers of High Stability.

21. Nergis, D.D.B.; Abdullah, M.M.A.B.; Vizureanu, P.; Tahir, M.F.M. Geopolymers and Their Uses: Review. IOP Conf. Series: Mater. Sci. Eng. 2018, 374, 012019. [CrossRef]

22. Davidovits, J. Geopolymer Chemistry and Sustainable Development. The Poly(Sialate) Terminology: A Very Useful and Simple Model for the Promotion and Understanding of Green-Chemistry; Geopolymer Institute: Saint-Quentin, France, 2005.

23. Bayuaji, R.; Yasin, A.K.; Susanto, T.E.; Darmawan, M.S. A review in geopolymer binder with dry mixing method (geopolymer cement). AIP Conf. Proc. 2017, 1887, 020022. [CrossRef]

24. Mozumder, R.A.; Laskar, A.I. Prediction of unconfined compressive strength of geopolymer-stabilised clayey soils using artificial neural network. Comput. Geotech. 2015, 69, 291-300. [CrossRef]

25. Lopes, A.V.; Lopes, S.M.R.; Pinto, I. Influence of the Composition of the Activator on Mechanical Characteristics of a Geopolymer. Appl. Sci. 2020, 10, 3349. [CrossRef] 
26. Van Deventer, J.; Provis, J.; Duxson, P.; Lukey, G. Reaction mechanisms in the geopolymeric conversion of inorganic waste to useful products. J. Hazard. Mater. 2007, 139, 506-513. [CrossRef] [PubMed]

27. Phetchuay, C.; Horpibulsuk, S.; Arulrajah, A.; Suksiripattanapong, C.; Udomchai, A. Strength development in soft marine clay stabilized by fly ash and calcium carbide residue based geopolymer. Appl. Clay Sci. 2016, 127-128, 134-142. [CrossRef]

28. Damilola, O.M. Syntheses, Characterization and Binding Strength of Geopolymers: A Review. Int. J. Mater. Sci. Appl. 2013, 2, 185. [CrossRef]

29. Palomoa, A.; Grutzeck, M.W.; Blanco, M.T. Alkali-activated fly ashes: A cement for the future. Cem. Concr. Res. 1999, 29, 1323-1329. [CrossRef]

30. Rees, C.; Lukey, G.C.; Van Deventer, J.S.J. The role of solid silicates on the formation of geopolymers derived from coal ash. In Proceedings of the International Symposium of Research Student on Material Science and Engineering, Chennai, India, 20-22 December 2004; pp. 1-13.

31. Jae, E.O.; Paulo, J.M.; Monteiro, S.S.; Jun, S.C.; Simon, M.C. The Evolution of Strength and Crystalline Phases for Alkali-activated Ground Blast Furnace Slag and Fly Ash-based Geopolymers. Cem. Concr. Res. 2010, 40, 189-196.

32. Altan, E.; Erdoğan, S.T. Alkali activation of a slag at ambient and elevated temperatures. Cem. Concr. Compos. 2012, 34, 131-139. [CrossRef]

33. Granizo, M.L.; Blanco, M.T. Alkaline activation of metakaolin an isothermal conduction calorimetry study. J. Ther. Anal. 1998, 52, 957-965. [CrossRef]

34. Davidovits, J. Chemistry of Geopolymeric Systems, Terminology. In Proceedings of the Second International Conference Geopolumère, Saint-Quentin, France, 30 June-2 July 1999; pp. 9-40.

35. Habert, G.; Roussel, N. Study of two concrete mix-design strategies to reach carbon mitigation objectives. Cem. Concr. Compos. 2009, 31, 397-402. [CrossRef]

36. Chungsangunsit, T.; Gheewala, S.H.; Patumsawad, S. Emission Assessment of Rice Husk Combustion for Power Production. World Acad. Sci. Eng. Technol. 2009, 29, 1064-1069.

37. Turner, L.K.; Collins, F.G. Carbon dioxide equivalent $\left(\mathrm{CO}_{2}-\mathrm{e}\right)$ emissions: A comparison between geopolymer and OPC cement concrete. Constr. Build. Mater. 2013, 43, 125-130. [CrossRef]

38. Azad, N.; Samarakoon, S. Utilization of Industrial By-Products/Waste to Manufacture Geopolymer Cement/Concrete. Sustainability 2021, 13, 873. [CrossRef]

39. Vitale, E.; Russo, G.; Dell'Agli, G.; Ferone, C.; Bartolomeo, C. Mechanical Behaviour of Soil Improved by Alkali Activated Binders. Environments 2017, 4, 80. [CrossRef]

40. Ghadir, P.; Ranjbar, N. Clayey soil stabilization using geopolymer and Portland cement. Constr. Build. Mater. 2018, 188, 361-371. [CrossRef]

41. Canakci, H.; Güllü, H.; Alhashemy, A. Performances of Using Geopolymers Made with Various Stabilizers for Deep Mixing. Materials 2019, 12, 2542. [CrossRef] [PubMed]

42. Abdullah, H.H.; Shahin, M.A.; Walske, M.L.; Karrech, A. Cyclic behaviour of clay stabilised with fly-ash based geopolymer incorporating ground granulated slag. Transp. Geotech. 2021, 26, 100430. [CrossRef]

43. Phummiphan, I.; Horpibulsuk, S.; Sukmak, P.; Chinkulkijniwat, A.; Arulrajah, A.; Shen, S.-L. Stabilisation of marginal lateritic soil using high calcium fly ash-based geopolymer. Road Mater. Pavement Des. 2016, 17, 877-891. [CrossRef]

44. Cristelo, N.; Glendinning, S.; Pinto, A.T. Deep soft soil improvement by alkaline activation. Proc. Inst. Civ. Eng.-Ground Improv. 2011, 164, 73-82. [CrossRef]

45. Sukmak, P.; Horpibulsuk, S.; Shen, S.-L. Strength development in clay-fly ash geopolymer. Constr. Build. Mater. 2013, 40, 566-574. [CrossRef]

46. Yaghoubi, M.; Arulrajah, A.; Disfani, M.M.; Horpibulsuk, S.; Leong, M. Compressibility and strength development of geopolymer stabilized columns cured under stress. Soils Found. 2020, 60, 1241-1250. [CrossRef]

47. Phetchuay, C.; Horpibulsuk, S.; Suksiripattanapong, C.; Chinkulkijniwat, A.; Arulrajah, A.; Disfani, M.M. Calcium carbide residue: Alkaline activator for clay-fly ash geopolymer. Constr. Build. Mater. 2014, 69, 285-294. [CrossRef]

48. Coudert, E.; Paris, M.; Deneele, D.; Russo, G.; Tarantino, A. Use of alkali activated high-calcium fly ash binder for kaolin clay soil stabilisation: Physicochemical evolution. Constr. Build. Mater. 2019, 201, 539-552. [CrossRef]

49. Abdullah, H.H.; Shahin, M.A.; Walske, M.L. Geo-mechanical behavior of clay soils stabilized at ambient temperature with fly-ash geopolymer-incorporated granulated slag. Soils Found. 2019, 59, 1906-1920. [CrossRef]

50. Cristelo, N.; Glendinning, S.; Fernandes, L.S.G.; Pinto, A.T. Effect of calcium content on soil stabilisation with alkaline activation. Constr. Build. Mater. 2012, 29, 167-174. [CrossRef]

51. Araújo, N.; Corrêa-Silva, M.; Miranda, T.; Gomes, A.T.; Castro, F.; Teixeira, T.; Cristelo, N. Unsaturated Response of Clayey Soils Stabilised with Alkaline Cements. Molecules 2020, 25, 2533. [CrossRef]

52. Alsafi, S.; Farzadnia, N.; Asadi, A.; Huat, B.K. Collapsibility potential of gypseous soil stabilized with fly ash geopolymer; characterization and assessment. Constr. Build. Mater. 2017, 137, 390-409. [CrossRef]

53. Zhang, M.; Guo, H.; El-Korchi, T.; Zhang, G.; Tao, M. Experimental feasibility study of geopolymer as the next-generation soil stabilizer. Constr. Build. Mater. 2013, 47, 1468-1478. [CrossRef]

54. Guo, Q.; Wei, M.; Wu, H.; Gu, Y. Strength and micro-mechanism of MK-blended alkaline cement treated high plasticity clay. Constr. Build. Mater. 2019, 236, 117567. [CrossRef] 
55. Samuel, R.; Puppala, A.; Radovic, M. Sustainability Benefits Assessment of Metakaolin-Based Geopolymer Treatment of High Plasticity Clay. Sustainability 2020, 12, 10495. [CrossRef]

56. Wang, S.; Xue, Q.; Zhu, Y.; Li, G.; Wu, Z.; Zhao, K. Experimental study on material ratio and strength performance of geopolymerimproved soil. Constr. Build. Mater. 2021, 267, 120469. [CrossRef]

57. Žiūrinkas, D.; Vaiciukyniene, D.; Stelmokaitis, G.; Dorosevas, V. Clayey Soil Strength Improvement by Using Alkali Activated Slag Reinforcing. Minerals 2020, 10, 1076. [CrossRef]

58. Bilondi, M.P.; Toufigh, M.M.; Toufigh, V. Experimental investigation of using a recycled glass powder-based geopolymer to improve the mechanical behavior of clay soils. Constr. Build. Mater. 2018, 170, 302-313. [CrossRef]

59. Bilondi, M.P.; Toufigh, M.M.; Toufigh, V. Using calcium carbide residue as an alkaline activator for glass powder-clay geopolymer. Constr. Build. Mater. 2018, 183, 417-428. [CrossRef]

60. Xiao, R.; Polaczyk, P.; Zhang, M.; Jiang, X.; Zhang, Y.; Huang, B.; Hu, W. Evaluation of Glass Powder-Based Geopolymer Stabilized Road Bases Containing Recycled Waste Glass Aggregate. Natl. Acad. Sci. Transp. Res. Rec. 2020, 2674, 22-32. [CrossRef]

61. Cyr, M.; Idir, R.; Poinot, T. Properties of inorganic polymer (geopolymer) mortars made of glass cullet. J. Mater. Sci. 2012, 47, 2782-2797. [CrossRef]

62. Hamada, H.M.; Jokhio, G.A.; Yahaya, F.M.; Humada, A.M.; Gul, Y. The present state of the use of palm oil fuel ash (POFA) in concrete. Constr. Build. Mater. 2018, 175, 26-40. [CrossRef]

63. Abdeldjouad, L. Effect of Curing Temperature on the Development of Hard Structure of Alkali-Activated Soil. Int. J. GEOMATE 2019, 17, 117-123. [CrossRef]

64. Phummiphan, P.I.; Horpibulsuk, P.S.; Phoo-Ngernkham, T.; Arulrajah, P.A.; Shen, S.-L. Marginal Lateritic Soil Stabilized with Calcium Carbide Residue and Fly Ash Geopolymers as a Sustainable Pavement Base Material. J. Mater. Civ. Eng. 2017, 29, 04016195. [CrossRef]

65. European Committee for Standardization (CEN). EN 16907-4:2018: Earthworks 2018 Soil Treatment with Lime And/or Hydraulic Binders; European Committee for Standardization (CEN): Brussels, Belgium, 2018.

66. Eyo, E.; Ng'Ambi, S.; Abbey, S.J. Incorporation of a nanotechnology-based additive in cementitious products for clay stabilisation. J. Rock Mech. Geotech. Eng. 2020, 12, 1056-1069. [CrossRef]

67. Abbey, S.J.; Eyo, E.U.; Okeke, C.A.; Ngambi, S. Experimental study on the use of RoadCem blended with by-product cementitious materials for stabilisation of clay soils. Constr. Build. Mater. 2021, 280, 122476. [CrossRef]

68. Gross, J.; Adaska, W. Guide to Cement-Stabilized Subgrade Soils; Portland Cement Association: Washington, DC, USA; National Concrete Pavement Technology Center, Iowa State University: Ames, IA, USA, 2020.

69. Van Jaarsveld, J.G.S.; van Deventer, J.S.J. Effect of the Alkali Metal Activator on the Properties of Fly Ash-Based Geopolymers. Ind. Eng. Chem. Res. 1999, 38, 3932-3941. [CrossRef]

70. Bakri, A.M.M.A.; Kamarudin, H.; Omar, V.; Norazian, M.N.; Ruzaidi, C.M.; Rafiza, A.R. Effects of Alkali Activator Ratio on the Compressive Strength of Fly Ash-Based Geopolymers. Austrialian J. Basic Appl. Sci. 2011, 5, 1916-1922.

71. Lizcano, M.; Kim, H.S.; Basu, S.; Radovic, M. Mechanical properties of sodium and potassium activated metakaolin-based geopolymers. J. Mater. Sci. 2012, 47, 2607-2616. [CrossRef]

72. McCormick, A.V.; Bell, T. The Solution Chemistry of Zeolite Precursors. Catal. Rev. Sci. Eng. 1989, 31, 97-127. [CrossRef]

73. Weldes, H.H.; Lange, K.R. Properties of Soluble Silicates. Ind. Eng. Chem. 1969, 61, 29-44. [CrossRef]

74. Salimi, M.; Ghorbani, A. Mechanical and compressibility characteristics of a soft clay stabilized by slag-based mixtures and geopolymers. Appl. Clay Sci. 2020, 184, 105390. [CrossRef]

75. Abbey, S.J.; Eyo, E.U.; Ng'Ambi, S. Swell and microstructural characteristics of high-plasticity clay blended with cement. Bull. Int. Assoc. Eng. Geol. 2019, 79, 2119-2130. [CrossRef]

76. Leong, H.Y.; Ong, D.E.L.; Sanjayan, J.; Nazari, A. Suitability of Sarawak and Gladstone fly ash to produce geopolymers: A physical, chemical, mechanical, mineralogical and microstructural analysis. Ceram. Int. 2016, 42, 9613-9620. [CrossRef]

77. Abdullah, H.H.; Shahin, M.A.; Sarker, P. Use of Fly-Ash Geopolymer Incorporating Ground Granulated Slag for Stabilisation of Kaolin Clay Cured at Ambient Temperature. Geotech. Geol. Eng. 2019, 37, 721-740. [CrossRef]

78. Jiang, N.-J.; Du, Y.-J.; Liu, K. Durability of lightweight alkali-activated ground granulated blast furnace slag (GGBS) stabilized clayey soils subjected to sulfate attack. Appl. Clay Sci. 2018, 161, 70-75. [CrossRef]

79. Kwasny, T.A.; Soutsos, A.M.N.; McIntosh, J.A.; Cleland, D.J. Sulfate and acid resistance of lithomarge-based geopolymer mortars. Constr. Build. Mater. 2018, 166, 537-553. [CrossRef]

80. Bakharev, T. Durability of geopolymer materials in sodium and magnesium sulfate solutions. Cem. Concr. Res. 2005, 35, 1233-1246. [CrossRef] 